NBER WORKING PAPER SERIES

THE IMPORTANCE OF BELIEFS IN SHAPING MACROECONOMIC OUTCOMES

\author{
Roger Farmer \\ Working Paper 26557 \\ http://www.nber.org/papers/w26557 \\ NATIONAL BUREAU OF ECONOMIC RESEARCH \\ 1050 Massachusetts Avenue \\ Cambridge, MA 02138 \\ December 2019, Revised May 2020
}

I would like to thank David Vines for encouraging me to write this paper. The current version has benefitted from the comments of Leland E. Farmer, Ken Mayhew, David Vines and two anonymous referees and from the helpful feedback of C. Roxanne Farmer. The views expressed herein are those of the author and do not necessarily reflect the views of the National Bureau of Economic Research.

NBER working papers are circulated for discussion and comment purposes. They have not been peer-reviewed or been subject to the review by the NBER Board of Directors that accompanies official NBER publications.

(C) 2019 by Roger Farmer. All rights reserved. Short sections of text, not to exceed two paragraphs, may be quoted without explicit permission provided that full credit, including () notice, is given to the source. 
The Importance of Beliefs in Shaping Macroeconomic Outcomes

Roger Farmer

NBER Working Paper No. 26557

December 2019, Revised May 2020

JEL No. D50,E12,E24,E32

\section{ABSTRACT}

For the past thirty years of the history of macroeconomic thought, the Indeterminacy School of Macroeconomics has used general equilibrium models with indeterminate equilibria to understand the independent role of beliefs in shaping macroeconomic outcomes. In this paper I review the most recent advances in the indeterminacy agenda, Keynesian Search Theory, and I advance that agenda by introducing self-fulfilling beliefs to a Keynesian Search model in two different ways. One variant of the model is driven by an exogenous process for investment expenditure. If investment is exogenous, the only way to restore full employment is by replacing private investment with public investment. The second variant of the model is driven by consumer confidence. If consumer confidence is exogenous, treasury or central bank intervention in the asset markets is a more effective means of restoring full employment than fiscal policy. In either scenario, increased government consumption will not be effective at maintaining full employment in the face of permanently depressed beliefs about the value of private assets.

Roger Farmer

UCLA

Department of Economics

Box 951477

Los Angeles, CA 90095-1477

and CEPR

and also NBER

rfarmer@econ.ucla.edu 


\title{
The importance of beliefs in shaping macroeconomic outcomes ${ }^{1}$
}

\begin{abstract}
For the past thirty years of the history of macroeconomic thought, the Indeterminacy School of Macroeconomics has used general equilibrium models with indeterminate equilibria to understand the independent role of beliefs in shaping macroeconomic outcomes. In this paper I review the most recent advances in the indeterminacy agenda, Keynesian Search Theory, and I advance that agenda by introducing self-fulfilling beliefs to a Keynesian Search model in two different ways. One variant of the model is driven by an exogenous process for investment expenditure. If investment is exogenous, the only way to restore full employment is by replacing private investment with public investment. The second variant of the model is driven by consumer confidence. If consumer confidence is exogenous, treasury or central bank intervention in the asset markets is a more effective means of restoring full employment than fiscal policy. In either scenario, increased government consumption will not be effective at maintaining full employment in the face of permanently depressed beliefs about the value of private assets.
\end{abstract}

JEL D50, E12, E24, E32

\section{INTRODUCTION}

The work I describe in this paper is part of the Indeterminacy School, a research agenda in the history of macroeconomics that exploits the indeterminacy of general equilibrium models to explain macroeconomic phenomena. The early papers in this school used models of dynamic indeterminacy to explain how beliefs independently influence outcomes. ${ }^{2}$ Here I describe advances from the past ten years which use general equilibrium models with steadystate indeterminacy to model what Keynes referred to as involuntary unemployment. ${ }^{3}$ I call these advances, Keynesian Search Theory (Farmer, 2016, p. 77).

\footnotetext{
${ }^{1}$ I would like to thank David Vines for encouraging me to write this paper. The current version has benefitted from the comments of Leland E. Farmer, Ken Mayhew, David Vines and two anonymous referees and from the helpful feedback of C. Roxanne Farmer.

${ }^{2}$ Farmer (1993) and Benhabib and Farmer (1999) (Cherrier \& Saïdi, 2018).

3 The Keynesian Search Model is summarized in De Vroey's book on the history macroeconomic thought (De Vroey, 2016) and the history of the Indeterminacy School in macroeconomics is documented in (Farmer, 2020). Some of the papers that use the Keynesian search approach are framed in a model without capital where beliefs are formed over the current value of an asset in fixed supply. These include (Farmer, 2008b) (2012a) (2013) and 
Keynesian Search Theory provides a way of explaining why high unemployment can sometimes persist for decades at a time. It is distinct from New-Keynesian economics which retains the pre-Keynesian idea that the economy is self-correcting. Keynesian Search Theory, in contrast, models Keynes' idea that the economy may become stuck in an equilibrium with high involuntary unemployment.

In New-Keynesian models, employment is temporarily away from its socially optimal level because wages and prices are sticky. This assumption may be a good characterization of market economies in normal times. It is not a good characterization of the Great Depression where nominal wages and nominal prices in the United States fell by $25 \%$ between 1929 and 1933 and where employment and consumption both fell substantially at the same time that the real wage increased.

By treating high unemployment as a temporary phenomenon caused by sticky wages or sticky prices, New Keynesian economics rejects two of the most important theoretical innovations of Keynes' General Theory (Keynes, 1936). These two innovations are: 1) High involuntary unemployment is an equilibrium phenomenon and: 2) the equilibrium is selected by the 'animal spirits' of investors (Farmer, 2010a). Keynesian search theory does capture these two key ideas from The General Theory. In Keynesian Search Theory, in contrast to New Keynesian economics, the economy will not return to full employment, except by chance, without active intervention by the fiscal or monetary policy makers.

Although Keynesian Search Theory draws its inspiration from Keynes, it is not a simple rehash of the interpretations of Keynesian economics offered by Hicks and Hansen, the architects of the IS-LM model. ${ }^{4}$ By providing a dynamic theory of aggregate demand and a logically consistent explanation for involuntary unemployment, Keynesian Search Theory provides a framework to assess the likely benefits of fiscal policy as a means of restoring and maintaining full employment. An important conclusion of the theory is that asset market intervention through the active control of the stock market is a more effective tool than traditional fiscal policy to increase welfare.

Sections II through VIII of this paper place Keynesian Search Theory in historical context and survey existing literature, much of which is in the context of models without reproducible capital. A notable exception is the work of Plotnikov, (Plotnikov, 2013) (Plotnikov, 2019) who developed a version of Keynesian Search Theory with reproducible capital. Plotnikov's dissertation used a device that I developed in my 2010 book, Expectations Employment and Prices (Farmer, 2010) in which consumption, investment and GDP are measured in wage units. That device made the model difficult to compare with more standard classical and New Keynesian models that use the GDP deflator to measure real variables. Sections IX - XI of

(Guerrazzi, 2011). (Heathcote \& Perri, 2018) (Kocherlakota, 2011) (2012) and (Michaillet \& Saez, 2015) construct related models that display multiple steady state equilibria. Empirical work that seeks to substantiate the empirical link from asset values to unemployment include (Farmer, 2012b) (2015), (Arabaci, 2017) (Miao, Wang, \& Xu, 2015) and (Pan, 2018). Papers that build models with capital and steady-state indeterminacy include (Beningno \& Fornaro, 2018), (Farmer, 2010b) (Gelain \& Guerrazzi, 2010), (Guerrazzi, 2012), (Plotnikov, 2019) and (Shea, 2013). The implications of steady-state indeterminacy have been explored in models with money (Farmer \& Platonov, 2019), and the empirical content of models with indeterminate steadystates for the Phillips curve has been explored in Farmer and Nicolò (2018), (2019). Farmer (2014) contains a survey of the literature on steady-state indeterminacy.

${ }^{4}$ The IS-LM model is a textbook interpretation of The General Theory that has been taught to several generations of undergraduates following the attempts by (Hansen, 1936) and (Hicks, 1937) to reconcile Keynesian economics with general equilibrium theory. For a contemporary reinvention of the IS-LM approach that uses Keynesian Search Theory, see (Farmer \& Platonov, 2019). 
this paper develop a more standard version of a model with capital and study two different assumptions about beliefs as alternative ways of closing the model.

\section{THE INTELLECTUAL HISTORY OF KEYNESIAN ECONOMICS 5}

At the risk of oversimplification, the history of macroeconomics began with the publication of The General Theory of Employment Interest and Money (Keynes, 1936). Before that date, economics was separated into price theory, which dealt with the determination of relative prices, and monetary theory, which dealt with the determination of the absolute level of prices in terms of money (Patinkin, 1956). The state of business cycle theory was captured by Pigou's book, Industrial Fluctuations (Pigou, 1923). ${ }^{6}$

Between 1929 and 1933, the stock market lost $80 \%$ of its value and the U.S. unemployment rate increased from $2 \%$ to $24 \%$. In the following decade, the unemployment rate never fell below $15 \%$ of the labour force. It is hard to envisage that period as one in which markets work well and, motivated by the immense social misery that was experienced by the unemployed, Keynes changed economics and politics forever.

The General Theory is a static verbal representation of an economy that does not contain a fully developed theory of inflation. In the three decades following its publication, macroeconomists sought to mathematize the General Theory and to equip it with a way of understanding the inflation that had arisen in the decades following the end of WWII. The apogee of Keynesian dominance of macroeconomics came in 1955 when Samuelson wrote the third edition of his textbook, Economics: An Introductory Analysis (Samuelson, 1955).

In the third edition of Economics, Samuelson introduced a new theory that he called the NeoClassical Synthesis. He meant by this, that the economy is Keynesian in the short run and classical in the long run (Pearce \& Hoover, 1995). Writing in Cambridge Massachusetts, Samuelson identified the short run as a period in which not all prices and wages have adjusted to their market-clearing levels. He identified the long run as the period in which prices and wages have adjusted to their market-clearing levels and employment has returned to its social planning optimum. Writing in Cambridge England, Joan Robinson referred to this development as 'bastard Keynesianism' (Robinson, 1978, p. 256).

Keynes' disciples in Cambridge England, Joan Robinson among them, resisted the Cambridge Massachusetts interpretation of the General Theory. This was due, in part, to the fact that evidence from the 1930s in the United States was hard to square with the assumption that the increase in unemployment was caused by wage or price stickiness. And although Keynes himself introduced money wage rigidity in Chapter 3, he did not believe that his theory rested on the assumption that money wages are rigid downwards. ${ }^{7}$

\footnotetext{
${ }^{5}$ This section summarizes the argument from How the Economy Works, (Farmer, 2010a).

${ }^{6}$ In Industrial Fluctuations, Pigou discusses multiple possible sources of, what today we would call, 'shocks' to the aggregate economy. Following a shock, the economy returns to a unique steady-state equilibrium in which the demands and supplies of all commodities are equal. In the language of modern general equilibrium theory, the steady-state equilibrium would be described as the solution to the problem of a social planner whose task is to maximize social welfare. In Pigou's conception of the aggregate economy, although markets are subject to shocks and to frictions that cause temporary deviations from market equilibrium, on balance, they work well.

${ }^{7}$ Here is what Keynes had to say:
}

In this summary we shall assume that the money-wage and other factor costs are constant per unit of labour employed. But this simplification, with which we shall dispense later, is introduced solely to facilitate the exposition. (Keynes, 1936, p. 27), my italics. 

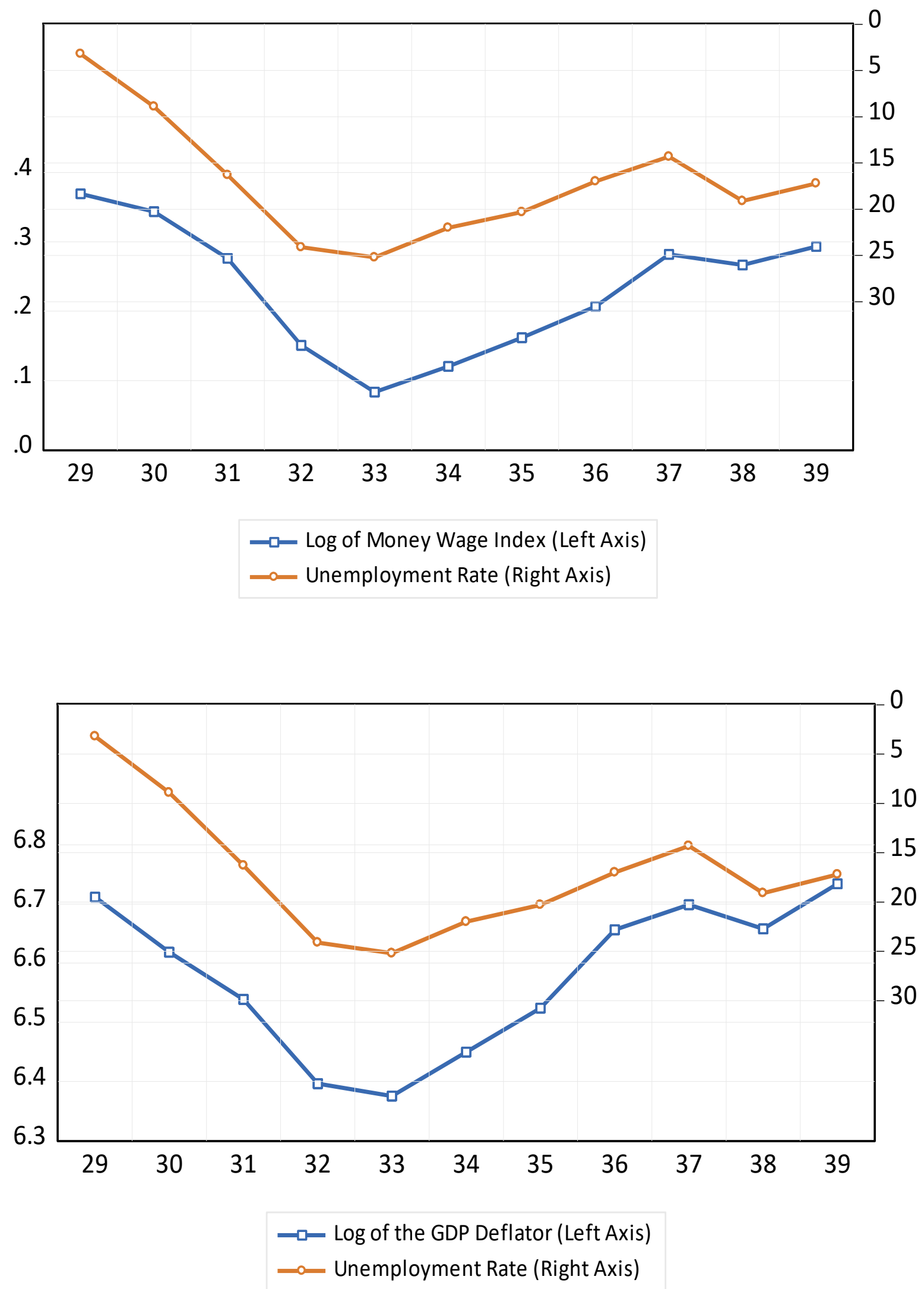

Figure 1: Wages, Prices and Unemployment During the Great Depression 
To understand why Keynes might not have been prepared to rest his theory on the assumption of downwards wage rigidity, I have presented some data for the decade from 1929 through 1939 in the United States in Figure 1. Writing in 1936, Keynes would have been aware of the fact that prices, wages and employment fell substantially in the United States between 1929 and 1933.

Figure 1 has two panels. In both panels the upper line, measured on the right axis on an inverted scale, is the unemployment rate. This scale runs from 0 to $30 \%$. On the top panel, the lower line, measured on the left axis, is the logarithm of a money wage index. On the bottom panel, the lower line, also measured on the left axis, is the logarithm of a price index.

The top panel of Figure 1 shows that the logarithm of the money wage index fell from 0.4 to 0.1 in the space of four years. The right panel shows that the logarithm of the GDP deflator fell from 6.7 to 6.4 over the same period. These changes mean that the money wage and the money price level in 1933 were each approximately $75 \%$ of their 1929 magnitudes. $^{8}$ While it is possible that prices and wages did not fall enough, this figure shows that there is little support for the proposition that money wages or money prices were rigid downwards in the largest recession in the United States in the last two hundred years.

In Chapter 19 of the General Theory, Keynes explains why he felt that his theory did not rest on the assumption of sticky wages and in Chapter 20 he extends his argument to provide an outline of a theory of price inflation. In that chapter he relates his ideas to the Quantity Theory of Money in a way that was picked up by Alvin Hansen (Hansen, 1936) and John Hicks (Hicks, 1937) in their development of what later became known as the IS-LM model.

Initially, the IS-LM model was taken to be a concise description of a key theme of the General Theory: in the face of deficient aggregate demand, high unemployment can be a permanent equilibrium of a modern market economy. That interpretation was destroyed by Patinkin (Patinkin, 1956) who showed that, in the IS-LM model, deflation can restore equilibrium by increasing the real value of nominal wealth.

I have given a short intellectual history of ideas. But this is not primarily a paper on the history of thought. My purpose is to understand how episodes like the Great Depression can occur in a modern market economy by providing a theory where unemployment can persist for long periods of time. In presenting Keynesian Search Theory as an alternative paradigm for macroeconomics, I will contrast it with the New-Keynesian paradigm, which explains high persistent unemployment by positing the existence of downwardly rigid money wages. ${ }^{9}$ I have presented the evidence in this section to demonstrate that in the largest depression of the last 200 years, wages and prices were demonstrably not rigid and yet unemployment did not fall below $15 \%$ for more than a decade.

\section{TEMPORARY EQUILIBRIUM THEORY: A FRAMEWORK FOR MODERN MACROECONOMICS}

The contribution of Hicks in his 1937 essay was to frame the General Theory in the context of Temporary Equilibrium Theory, a method of analysis that Hicks was working on at the time and that he published in Value and Capital (Hicks, 1939). Hick's method was picked up

\footnotetext{
${ }^{8}$ Expressing the change in levels leads to the following calculations. For the money wage $\exp (0.1) / \exp (0.4)=$ 0.74 and for the money price level, $\exp (6.4) / \exp (6.7)=0.74$.

${ }^{9}$ For a recent prominent example of this approach, see (Eggertsson, Mehrotra, \& Robbins, 2019). 
by Patinkin (Patinkin, 1956) in Money Interest and Prices, an important work that laid the groundwork for much of modern macroeconomic theory.

In Temporary Equilibrium Theory, one conceives of the world as proceeding in a sequence of weekly meetings. Each week, people come to market for the purpose of consumption, production and trade. They bring with them goods held over from the previous week and they bring a set of financial obligations to each other, also inherited from the past. At the market, they form expectations about what will happen at future market meetings and they produce, consume and trade with each other at a set of market prices.

This framework is widely used by macroeconomists to ask, and answer, two questions. First: given a set of existing contracts and a given a method of forming expectations about the future, how are quantities and prices determined each week? Different answers to this question are associated with different equilibrium concepts. Second: given an equilibrium concept for each market meeting, how do market participants form expectations about the future? Different answers to this question are associated with different expectations mechanisms.

Modern macroeconomics begins with the work of Robert Lucas (Lucas Jr., 1972). Lucas answered the first question with the market clearing assumption. He posited the existence a Deus ex Machina, the Walrasian Auctioneer, who calls out a vector of prices. The auctioneer asks each household how much of each commodity they want to buy or sell at those prices and he asks each firm how much of each commodity it plans to produce. Trades only take place once the auctioneer has arrived at a set of prices at which the quantities demanded and supplied of all commodities, including labour, are equal.

Lucas answered the second question by introducing the rational expectations assumption. People's expectations of future prices are equal to the prices that actually occur in every conceivable state of nature. Both assumptions are extremely strong. and together they had the effect of providing a mathematized version of pre-Keynesian ideas of the 1920s that are summarized in Pigou's book, Industrial Fluctuations (Pigou, 1923).

\section{THE CLASSICAL REPRESENTATION OF THE LABOUR MARKET}

I refer to a model closed with the assumptions of market clearing and rational expectations as the Classical Model. In this section, I explain why the Classical Model cannot easily explain the Great Depression.

The labour market equilibrium in the Classical Model is characterized by a pair of equations representing the demand and supply of labour. The first of these two equations is represented by Equation (1). This equation arises from the profit maximization condition of a representative firm. The left side of Equation (1) represents the marginal product of labour. The right side of Equation (1) represents the real wage.

$$
(1-\alpha) S_{t}\left(\frac{K_{t-1}}{L_{t}}\right)^{\alpha}=\frac{w_{t}}{p_{t}} .
$$

When plotted on a graph with the real wage on the vertical axis and employment on the horizontal axis, Equation (1) traces a downwards sloping labour-demand curve whose position is determined by capital, $K_{t-1}$ and productivity, $S_{t}$. The term $w_{t}$ is the money wage, $p_{t}$ is the money price of goods and $S_{t}$ is a random variable that represents shocks to labour 
productivity. The subscript $t$ represents calendar time. ${ }^{10}$ Writing in the General Theory, Keynes referred to a variant of Equation (1) as the first postulate of classical economics (Keynes, 1936, p. 5).

The second of the two labour market equations is represented by Equation (2). This equation arises from the utility maximization problem of a representative household. The left side of Equation (2) represents the disutility of work, measured relative to the marginal utility of consumption. The right side of Equation (2) represents the real wage.

$$
\frac{\gamma C_{t}}{1-L_{t}}=\frac{w_{t}}{p_{t}}
$$

When plotted on a graph with the real wage on the vertical axis and employment on the horizontal axis, Equation (2) traces an upward sloping labour-supply curve whose position is determined by aggregate consumption, $C_{t}$. An equation of this form is a second component of the formulation of labour market equilibrium in equilibrium business cycle models. In these models, a representative household maximizes the present discounted value of a sequence of period utility functions. ${ }^{11}$

Writing in The General Theory, Keynes referred to Equation (2) as the second postulate of classical economics (Keynes, 1936, p. 5). It is this equation that he sought to replace with an alternative theory in which employment is determined by aggregate demand.

To understand why Keynes rejected the second postulate of classical economics, it helps to fast forward forty years to the 1980s when the classical theory of business cycles was first formalized using the language of mathematics (Kydland \& Prescott, 1982; Long \& Plosser, 1983). This formulation, known as Real Business Cycle (RBC) theory, provides a complete dynamic theory of the determination of capital, employment, consumption and the real wage.

In the RBC formulation of the Classical Model, expenditure on consumption and expenditure on leisure are described by the equations,

$$
C_{\mathrm{t}}=\frac{(1-\beta)}{1+\gamma} W_{t}, \quad \text { and } \quad \frac{w_{t}}{p_{t}}\left(1-L_{t}\right)=\frac{\gamma(1-\beta)}{1+\gamma} W_{t},
$$

where $W_{t}$ is aggregate wealth and all variables are measured in units of date $t$ consumption goods. The wealth measure, $W_{t}$, is equal to the current stock of capital plus the discounted present value of the agent's endowment of time. The parameter $\beta$ is the rate at which the representative agent discounts expected future utility.

10 An equation of this form is an important component of simple equilibrium business cycle models in which a single aggregate commodity, $Y_{t}$, is produced from capital using a Cobb-Douglas technology,

$$
Y_{t}=S_{t} K_{t-1}^{\alpha} L_{t}^{1-\alpha}
$$

and where the parameter $\alpha$ represents the elasticity of production with respect to capital. I have adopted the timing convention that time subscripts denote the information set. Capital used at date $t$ is labelled $K_{t-1}$ because it is determined at date $t-1$.

${ }^{11}$ In writing Equation (2) I have assumed that the period utility function has the functional form,

$$
U_{t}=\log \left(C_{t}\right)+\gamma \log \left(1-L_{t}\right)
$$

and that the household has one unit of time to allocate every period between employment and leisure. The parameter $\gamma$ represents the household's preference for leisure and the term, $\gamma C_{t} /\left(1-L_{t}\right)$ is the slope of an indifference curve in consumption-leisure space for this functional form for utility. 

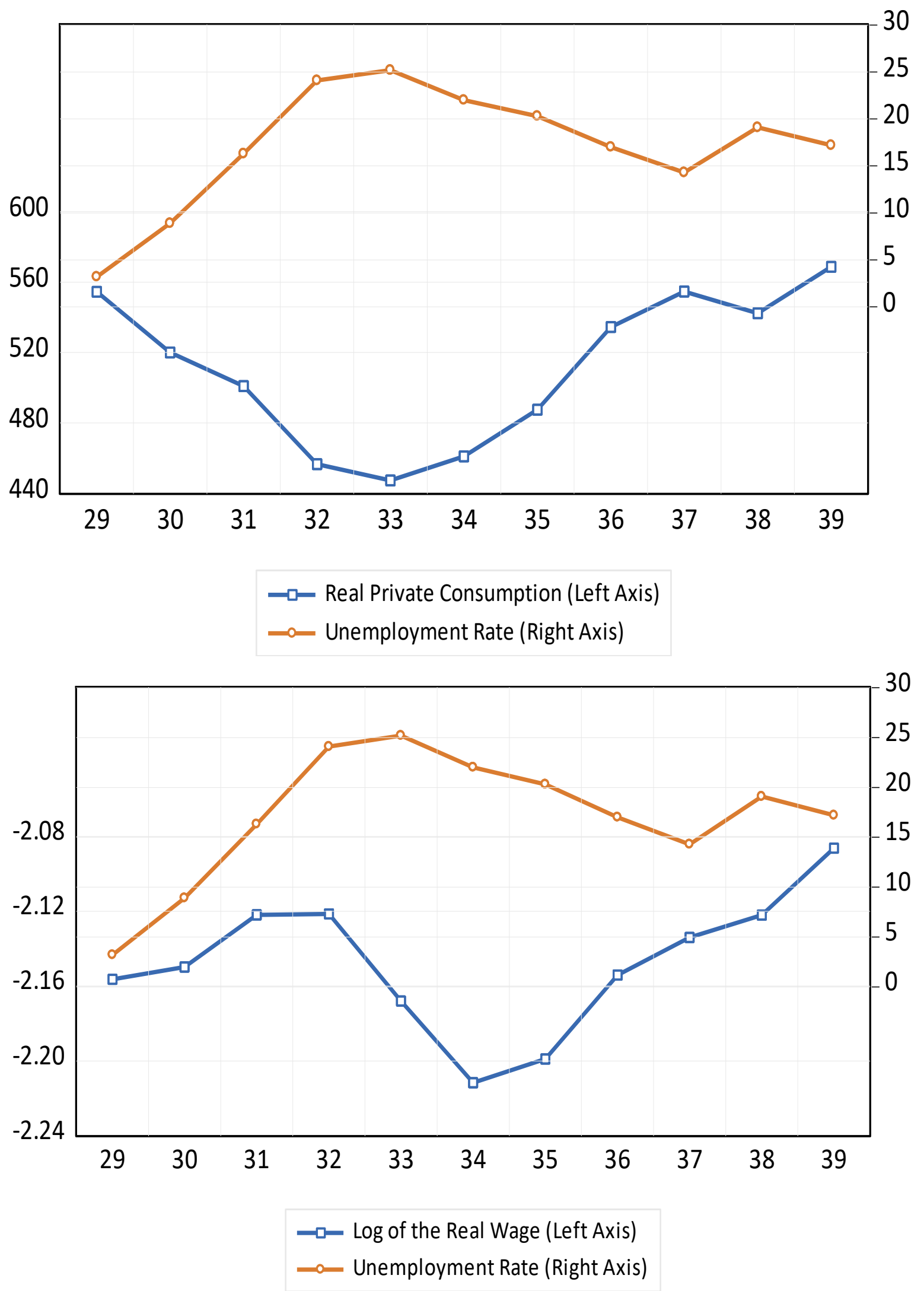

Figure 2: Consumption, Unemployment and the Real Wage During the Great Depression 
These equations predict that consumption and unemployment (the observable analogue of $1-L_{t}$ ) should both move in proportion to movements in wealth. This prediction is hard to square with the behaviour of consumption, unemployment and wages during the Great Depression, a point that was made by Barro and King with regard to the properties of the Classical Model more generally (Barro \& King, 1984).

I present the evidence for this assertion on Figure 2 which graphs consumption, unemployment and the real wage in the United States in the period from 1929 through 1939. On both panels of Figure 2, the upper line is the unemployment rate measured on the right axis. On the top panel, the lower line is real private consumption measured on the left axis in billions of 1987 dollars. On the bottom panel the lower line is the logarithm of the real wage.

The top panel of Figure 2 shows that consumption fell from 560 in 1929 to 440 in 1933, a drop of approximately $20 \%$. At the same time, unemployment, which is the classical analogue of leisure, increased by a factor of 12 from $2 \%$ of the labour force in 1929 to $24 \%$ of the labour force in 1933.

A negative co-movement between leisure and consumption of this magnitude is not easy to square with classical economics. Examining Equations (1) and (2), we see that if the real wage had remained constant, the classical theory predicts that consumption and leisure should both have fallen in proportion and both movements would have been associated with a fall in wealth. In the data, consumption and leisure moved in opposite directions.

One possibility, if the classical theory is correct, is that the real wage fell even more than employment rose. If this was the case, expenditure on leisure could have fallen even when time devoted to leisure increased. This possibility can be evaluated by examining the bottom panel of Figure 2. In the bottom panel of this figure, I show that the real wage increased in the first three years of the Depression and it only began to fall in 1932 at about the time when leisure also began to fall. These facts are hard to interpret through the lens of the Classical Model.

\section{SEARCH THEORY, UNEMPLOYMENT AND VACANCIES}

In the three decades following the publication of The General Theory, economists attempted to reconcile Keynesian economics with a classical theory of the labour market. Those attempts were abandoned in 1972 when Robert Lucas (1972) persuaded the profession to jettison the concept of involuntary unemployment. In Lucas' new formulation of 'rational expectations macroeconomics', economists were entreated to return to the two classical postulates of classical economics and to abandon the idea that beliefs are independent factors that determine outcomes.

In parallel to the development of rational expectations models of macroeconomics, economic theorists continued to pursue the theory of unemployment. In 1970, Edmund Phelps edited an influential collection of papers (Phelps, 1970) that presented theoretical interpretations of the microeconomics of inflation and unemployment. The eponymous Phelps volume created the field of search theory that was recognized in 2010 with three Nobel prizes; awarded to Peter Diamond, Dale Mortensen and Christopher Pissarides (DMP). I refer to DMP models as Classical Search Theory and I refer to my own work, and that of my students and co-authors, as Keynesian Search Theory. Classical Search Theory is surveyed by Pissarides (1990). ${ }^{12}$

\footnotetext{
12 In my book Prosperity for All, I coined the term Keynesian Search Theory to clearly differentiate my work and that of my students and co-authors from the IS-LM model and from classical search theory (Farmer, 2016, 
Search theory, in both its classical and Keynesian variants, differs from classical equilibrium theory in two ways. First, search theories assume that the process of matching a suitable worker with a suitable vacancy is costly and uses social resources. Second, search theories assume that the technology for matching unemployed workers with vacant job openings cannot be decentralized by markets.

To model the process of filling jobs, search theories posit the existence of a search technology, $m(\cdot)$,

$$
m=m(V, U),
$$

where $m$ is the number of new employment relationships created in a given period of time, $U$ is the number of unemployed workers and $V$ represents the resources allocated by firms to the process of filling vacancies. The search technology is a simple way of modelling the fact that the faster an economy fills vacant jobs, the more resources it must devote to the task of efficiently matching the right worker to the right vacancy.

We can describe the properties of the search technology by drawing a graph with unemployment on one axis and vacancies on the other. Alternative methods for filling 40,000 vacant jobs per week can be represented by downward sloping curves that represent the isoquants of the search technology, a concept that is similar to the isoquants in labour-capital space that are used to characterize production in standard microeconomic models (Farmer, 2016, pp. 76-78). ${ }^{13}$

This idea is illustrated in Figure 3, which plots the theoretical relationship between vacancies and unemployment implied by search theory. A relationship similar to this exists between unemployment and vacancies in empirical data in the UK and in the US. This relationship, called the Beveridge curve, is named after the UK politician William Beveridge.

To see how the assumption of costly recruiting modifies social opportunities, suppose that a fraction $\delta$ of workers separates exogenously from jobs in every period. Assume further that these people can be replaced by assigning $V$ workers to the task of recruiting and $X$ workers to the task of producing commodities where $X+V=L$; that is, every worker is assigned either to the production department, this is measured by $X$, or to the recruiting department, this is measured by $V$. These assumptions lead to the following dynamic equation to describe how employment changes through time

$$
L^{\prime}=(1-\delta) L+m(V, 1-L),
$$

where $1-L=U$ is the aggregate unemployment rate and $L^{\prime}$ is employment in the subsequent period. In a steady state in which $L$ is the same every period, this equation simplifies to the expression, $\delta L=m(V, 1-L)$ which says that job creation, this is the term $m(V, 1-L)$, equals job destruction, this is the term $\delta L$.

p. 77). In previously published works, I referred to the Keynesian Search Model as Old-Keynesian economics (Farmer, 2008a) (Farmer, 2008b).

13 In empirical work one must choose a functional form for $m(\cdot)$. Here, I will use the example

$$
m(V, U) \equiv(\Gamma V)^{\frac{1}{2}} U^{\frac{1}{2}},
$$

to fix ideas. This functional form is widely used in search models and it is the one I have used in my own work on Keynesian search theory (Farmer, 2008b) (2012a) (2013). The exponent of $1 / 2$ on $U$ and $V$ determines the slope of the Beveridge curve (see Figure 3 ) and the parameter $\Gamma$ can be calibrated to fit the steady-state unemployment rate. 


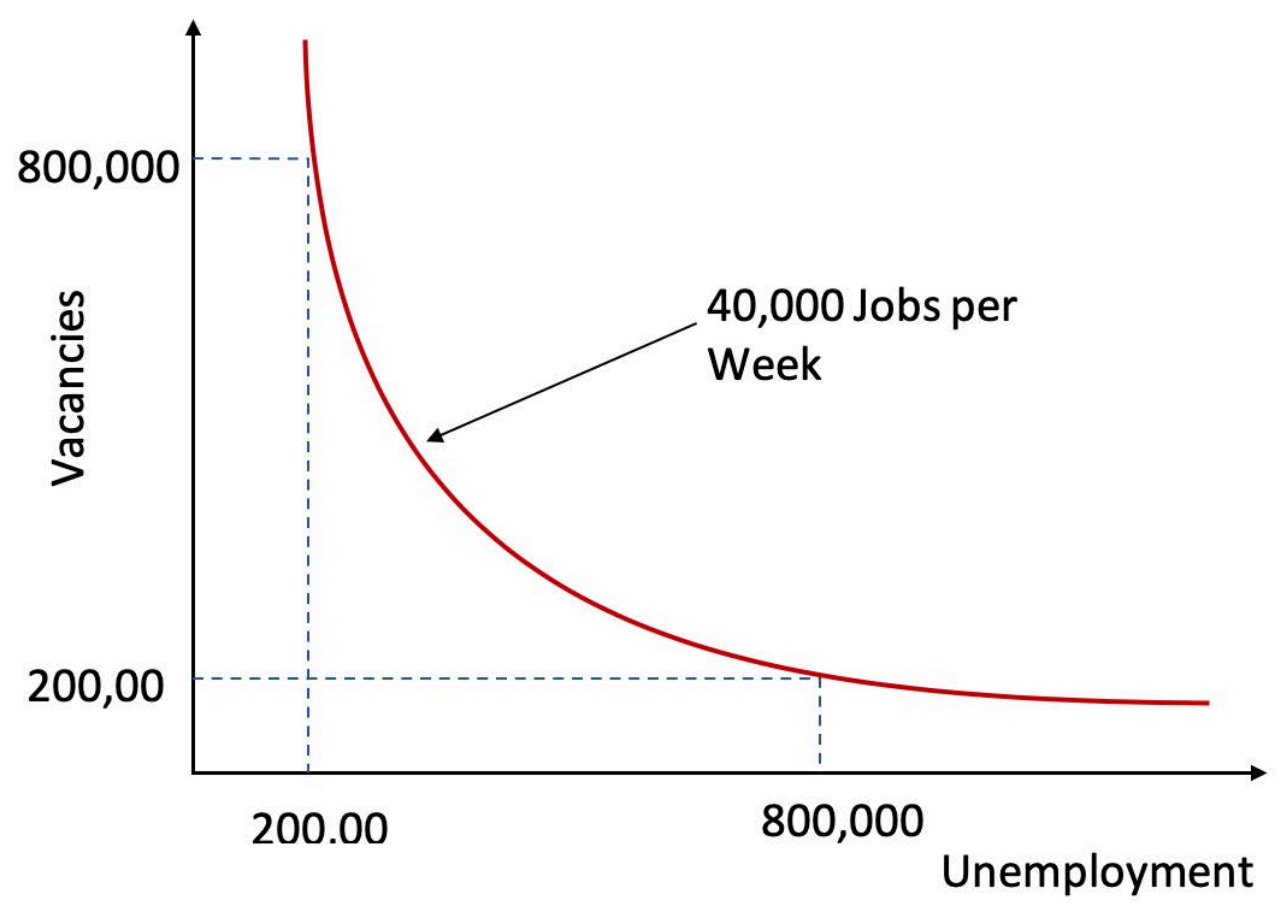

Figure 3: The Beveridge Curve ${ }^{14}$

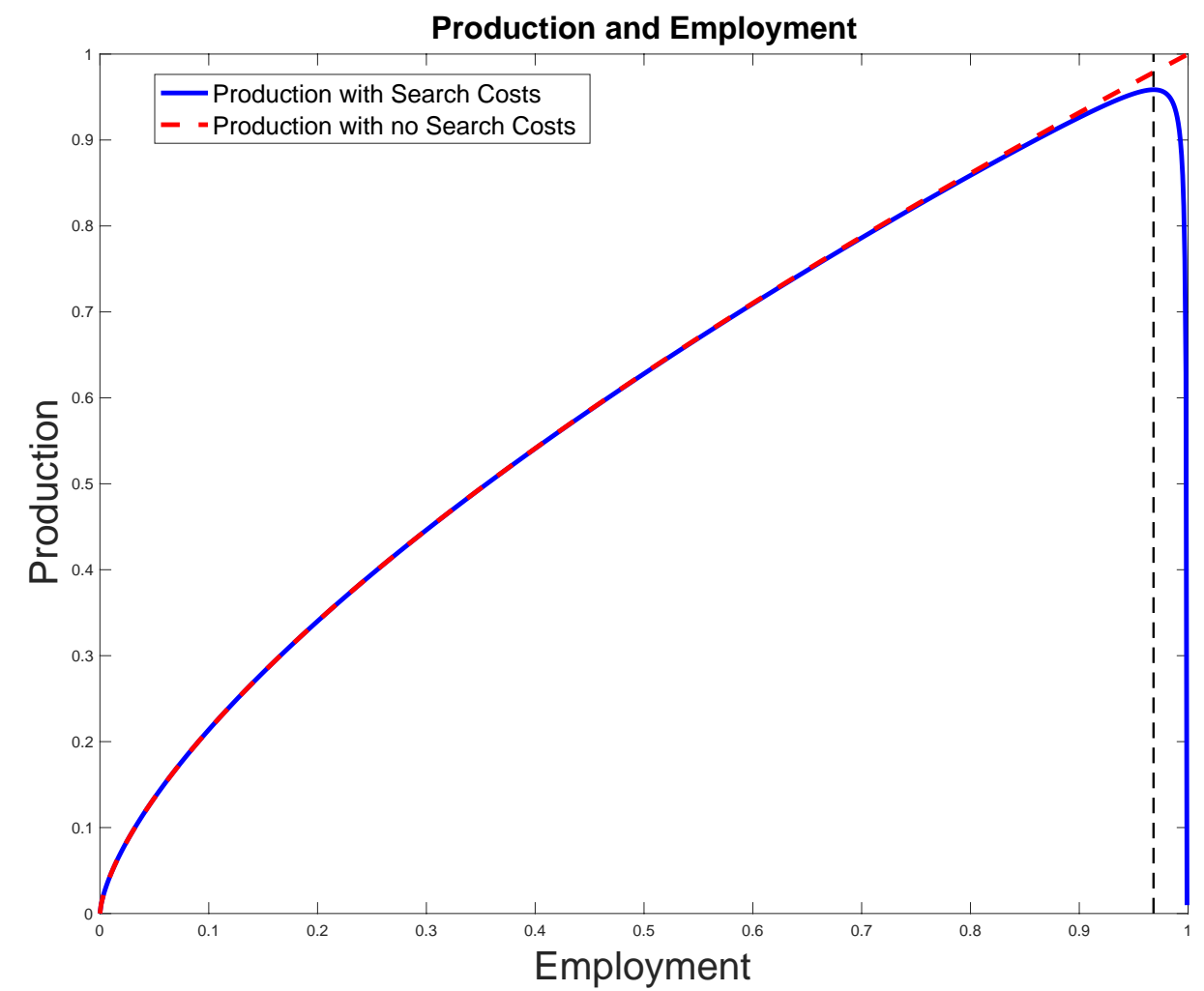

Figure 4: Production and Employment in a Search Model

${ }^{14}$ Source: (Farmer, Prosperity for All: How to Prevent Financial Crises, 2016) page 80. 
If we were to ask a social planner to maximize steady state GDP, this equation places a constraint on his choices. Because $m(\cdot)$ is an increasing function of $V$, the social planner can speed up the rehiring process by allocating a larger fraction of the labour force to recruiting as opposed to production. But assigning more workers to recruiting reduces the number of workers available to produce goods and generates the steady-state production function graphed in Figure 4.

Figure 4 compares the steady state value of GDP as a function of employment for two different technologies; one with and one without search costs. The technology with search costs is defined by the expression,

$$
Y=\phi(L) \equiv X^{b}, \quad X \equiv L\left(1-\frac{\delta^{2} L}{\Gamma(1-\mathrm{L}}\right),
$$

where the variable $X \equiv L-V$ represents the workers assigned to the activity of production as opposed to recruiting. The function $\phi(L)$ is labelled as 'production with search costs' and it is graphed as the solid upward sloping curve on Figure $4 .{ }^{15}$ For comparison I have drawn the function,

$$
Y=L^{b} .
$$

This is labelled as 'production with no search costs'. For levels of employment from $L=0$ to $L=0.9$, these two functions are almost indistinguishable. For the production technology with search costs, steady-state production peaks at an unemployment rate of $3.2 \%{ }^{16}$

The fact that these two technologies are almost indistinguishable except at very high levels of capacity utilization implies that total employment, $L$, and employment used to produce goods, $X$, are approximately equal for most values of employment. I will exploit that fact in Sections $\mathrm{X}$ and XI in which I study the response of the Keynesian Search Model to two different kinds of belief shocks.

\section{THE STEADY STATE INDETERMINACY OF CLASSICAL AND KEYNESIAN SEARCH THEORIES}

One can build a macroeconomic model that incorporates the main ideas from search theory by taking a one-good production economy and adding a search technology as in the work of Monica Merz (1995) and David Andolfatto (1996). ${ }^{17}$ The production technology is a blueprint for combining labour and capital to produce output. The search technology is a blueprint for combining employed labour with unemployed labour to produce employment in the subsequent period. Under neoclassical assumptions about the nature of these technologies, there is a unique assignment of workers to the tasks of production and recruiting that traces out an intertemporal production possibilities frontier.

\footnotetext{
${ }^{15}$ Figure 4 is based on the model described in (Farmer, 2013). The function $\phi(L)$ is generated by taking $K=1$ and using the equations $\delta L=m(V, 1-L)$ and $X+V=L$ to replace $X$ as a function of $L$ in the function $Y=$ $X^{b}$.

${ }^{16}$ Production is maximized when $L=1-\delta / \Gamma^{0.5}$. Here I set $\Gamma=10$ and $\delta=0.1$ which gives maximum produced output when the unemployment rate is $96.8 \%$.

17 The discussion in this section is drawn from my Economic Journal paper, "Confidence Crashes and Animal Spirits" (Farmer, 2012a).
} 
We know from the second welfare theorem of economics that, when the two technologies satisfy the assumption of constant returns-to-scale, it should be possible to decentralize the social planning problem using markets. What would that decentralization look like?

In a decentralized competitive equilibrium, a large number of competitive recruiting firms would purchase, from production firms, the exclusive right to fill their vacancies. They would purchase, from unemployed workers, the exclusive right to find them a job. Both of these inputs to the search technology would have a price. Competitive recruiting firms would match suitable workers to suitable production firms and sell the best match to the workerfirm pair. Markets of this kind would be associated with significant moral hazard problems and, in the real world, they are missing. ${ }^{18}$

Classical and Keynesian search theory both recognize this fact and both theories assume instead that firms randomly meet workers. Because there is no market for the time of a searching worker, the price that should record the marginal cost of that time does not exist. And because there is no market for the cost of the resources that a firm must devote to filling a vacancy, the price that should record the marginal cost of that activity does not exist either. The absence of these price signals causes Classical and Keynesian Search Theories, except in exceptional circumstances, to generate suboptimal outcomes.

There is nothing particularly subversive about the idea of adding a search technology to a competitive equilibrium model. One could, in principle, analyse a real business cycle model with a production technology and a search technology in the same way that one analyses a real business cycle model where search is costless. What makes Classical and Keynesian Search Theories different form a standard RBC model is the assumption that there is no Walrasian auctioneer to choose wages and prices in each market meeting. If one assumes that firms and workers are price takers, there are not enough relative prices to lead market participants to the right point on the Beveridge curve.

Classical Search Theory solves this conundrum by assuming that firms and workers are not price takers. Instead, when a firm meets a worker, the firm and the worker bargain over the wage. The theory introduces a new equation; the Nash bargaining equation. And it introduces a new parameter, the bargaining weight, which selects which point on the Beveridge curve is chosen in a classical search-market equilibrium.

Keynesian Search Theory uses the same conceptual apparatus as Classical Search Theory, but it retains the assumption that firms and workers are price takers. To resolve the indeterminacy which arises from an insufficiency of relative prices, Keynesian Search Theory adds a different new independent equation. Unlike Classical Search Theory, this is not an assumption about bargaining in the labour market. Instead, Keynesian Search Theory assumes that households form beliefs about the value of their assets. ${ }^{19}$ Beliefs are an independent exogenous determinant of aggregate demand. In Keynesian Search Theory, beliefs determine wealth, wealth determines the demand for produced goods and the demand for produced goods determines employment.

Table 1 summarizes the equations of the dynamic general equilibrium model developed in Farmer (2012a, p. 13). In that model, output is produced using land, assumed to be in fixed

\footnotetext{
${ }^{18}$ Why would an unemployed worker accept a job when she is paid to be unemployed? How could she be prevented from selling the exclusive right to match her skills to multiple recruiting firms? Because of the substantial informational asymmetries that characterize the search process, the markets for the inputs to the search technology do not, in practice, exist.

${ }^{19}$ I am using the term 'beliefs' interchangeably with what Keynes called 'animal spirits'.
} 
Table 1

Three Different Ways of Closing the Model

\begin{tabular}{|c|c|c|c|}
\hline & \multicolumn{3}{|c|}{ Equations in common } \\
\hline (T1) & \multicolumn{3}{|c|}{$\frac{1}{C_{t}}=\beta \mathbb{E}_{t}\left[\frac{1}{C_{t+1}} \frac{p_{t}}{p_{t+1}}\left(1+i_{t}\right)\right]$} \\
\hline (T2) & \multicolumn{3}{|c|}{$\left(1+i_{t}\right) \mathbb{E}_{t}\left(\frac{1}{C_{t+1}} \frac{p_{t}}{p_{t+1}}\right)=\mathbb{E}_{t}\left[\frac{1}{C_{t+1}} \frac{p_{t}}{p_{t+1}}\left(\frac{p_{k, t+1}+r r_{t+1}}{p_{k, t}}\right)\right]$} \\
\hline (T3) & \multicolumn{3}{|c|}{$b \frac{C_{t}}{L_{t}}=\frac{w_{t}}{p_{t}}$} \\
\hline \multirow[t]{3}{*}{ (T4) } & \multicolumn{3}{|c|}{$a C_{t+1}=\frac{r r_{t+1}}{p_{t}}$} \\
\hline & \multicolumn{3}{|c|}{ Equations that differ } \\
\hline & Walrasian Auction & $\begin{array}{c}\text { Classical Search } \\
\text { Theory }\end{array}$ & $\begin{array}{c}\text { Keynesian Search } \\
\text { Theory }\end{array}$ \\
\hline (T5) & $C_{t}=\left(S_{t} L_{t}\right)^{b}$ & $C_{t}=\left[S_{t} L_{t}\left(1-\frac{L_{t}}{\Gamma}\right)\right]^{b}$ & $C_{t}=\left[S_{t} L_{t}\left(1-\frac{L_{t}}{\Gamma}\right)\right]^{b}$ \\
\hline (T6) & $C_{t} L_{t}^{\gamma}=\frac{w_{t}}{p_{t}}$ & $\frac{b(1-\lambda) C_{t}}{L_{t}\left(1-L_{t} / \Gamma\right)}=\frac{w_{t}}{p_{t}}$ & $\mathbb{E}_{t}\left[\frac{p_{k, t+1}}{p_{t+1}}\right]=x_{t}$ \\
\hline
\end{tabular}

supply, and labour. All output is consumed. The complete model consists of six equations (T1) - (T6) in six unknowns. The unknowns are represented by the symbols,

$$
\left[C_{t}, \frac{\left(1+i_{t}\right) p_{t}}{p_{t+1}}, \frac{w_{t}}{p_{t}}, \frac{p_{k, t}}{p_{t}}, L_{t}, \frac{r r_{t}}{p_{t}}\right]
$$

which refer to consumption, the real interest rate, the real wage, the relative price of land, employment and the real rental rate for land. The money price, $p_{t}$, is a numeraire and as with all real general equilibrium models it is only relative prices that are determined by the model.

To simplify the exposition of the labour market, I assume that labour is fired and rehired every period. This stark assumption enables me to compare different assumptions about the labour market in the simplest possible environment. I close the model in three ways and I compare the properties of the three models. In Model 1 the labour market is closed with a Walrasian auction, in Model 2 it is closed with Classical Search Theory and in Model 3 it is closed with Keynesian Search Theory.

Equations (T1) - (T4) from Table 1 are in common to all three models. Equation (T1) is the Euler equation of a representative agent. This equation determines the allocation of the household between consumption and saving. Equation (T2) is a no-arbitrage condition. This equation must hold if the representative agent is to be indifferent to holding government bonds which pay a real return of 


$$
\frac{\left(1+i_{t}\right) p_{t}}{p_{t+1}}
$$

and capital which pays a real return of

$$
\frac{\frac{p_{t}}{p_{t+1}}\left(p_{k, t+1}+r r_{t+1}\right)}{p_{k, t}} .
$$

Equation (T3) is the demand curve for labour and it is the model's version of Equation (1) from Section IV page 6. Equation (T4) is the demand curve for land. Equations (T3) and (T4) come from the first order profit-maximizing conditions for labour and land in a model with Cobb-Douglas technologies and one unit of land in fixed supply.

Equation (T5) is the production function. For Model 1, summarized in column 1, the production function is given by the following equation which incorporates the assumption that all produced output is consumed,

$$
C_{t}=\left(S_{t} L_{t}\right)^{b},
$$

and where $S_{t}$ is a productivity shock. For models 2 and 3, summarized in columns 2 and 3 of Table 1, the production function is represented by the equation ${ }^{20}$

$$
C_{t}=\left[S_{t} L_{t}\left(1-\frac{L_{t}}{\Gamma}\right)\right]^{b}
$$

This production function' is a simplified form of $\phi(L)$ from Figure 4, modified to allow for the assumption that labour is fired and rehired every period. The term $1-\frac{L_{t}}{\Gamma}$ captures the resource cost of search.

\section{THE THREE MODELS COMPARED}

In Model 1, the household is endowed with one unit of time and it receives disutility from leisure. Leisure, consumption and land are traded every week in an auction mediated by the Walrasian Auctioneer and firms and workers have rational expectations of all future wages and prices.

In models 2 and 3, I drop the assumption that leisure yields disutility and I assume that households and firms meet randomly. The number of meetings each week between workers and firms is determined by the search technology,

$$
m=(\Gamma V)^{\frac{1}{2}} U^{\frac{1}{2}}
$$

Model 2 is an example of Classical Search Theory in which the firm and the worker bargain over the wage. Model 3 is a version of Keynesian Search Theory in which firms employ as many workers as are needed to meet the demand for their product and free entry causes wages to rise or fall to generate zero profits. Consider each of these models in turn.

\section{Model 1: The Walrasian Auctioneer}

In Model 1, the household chooses its labour supply to equate the disutility of work, measured in consumption units, to the real wage. This leads to a model of the labour market that mimics the Classical Model I discussed in Section IV,

\footnotetext{
${ }^{20}$ There is a typo in the published version of the table. The term $\left(1-\frac{L_{t}}{\Gamma}\right)$ should be raised to the power $b$.
} 


$$
C_{t} L_{t}^{\gamma}=\frac{w_{t}}{p_{t}}=\frac{b C_{t}}{L_{t}}
$$

The left side of this expression is the model's analogue of Equation 2 from Section IV page 7. It differs from Equation 2 because in my Economic Journal paper (Farmer, 2012a) I chose a different functional form for utility. The right side of the expression is Equation (T3) which is the model's analogue of Equation 1 from Section IV page 6. Solving for employment gives the expression

$$
L_{t}=b^{\frac{1}{1+\gamma}}
$$

This equation demonstrates that in the auction model, employment is constant. Fluctuations in the production of goods do occur, but they arise purely from productivity shocks. This result follows from two assumptions. First, that preferences are logarithmic which implies that the income and substitution effects of real wage movements cancel each other out. And second, there is no mechanism to transfer resources through time by accumulating capital.

\section{Model 2: Classical Search Theory}

Consider what happens in Classical Search Theory. In that theory, when a firm meets a worker the firm and the worker bargain over the real wage. When combined with free entry of firms, I show (Farmer, 2012a, p. 11) that this assumption leads to the equilibrium wage equation from column 2 ,

$$
\frac{b(1-\lambda) C_{t}}{L_{t}\left(1-\frac{L_{t}}{\Gamma}\right)}=\frac{w_{t}}{p_{t}}=\frac{b C_{t}}{L_{t}},
$$

where the parameter $\lambda$ is the bargaining weight of the worker. The left side of this expression is the wage equation of the classical search model, and the right side is the labour demand equation. Solving these equations for $L_{t}$ and combing this solution with definitions of vacancies and employment leads to the following expressions for employment, vacancies and unemployment

$$
L_{t}=\Gamma \lambda, \quad V_{t}=\Gamma \lambda^{2}, \quad U_{t}=1-\Gamma^{2} \lambda .
$$

Compare this to the solution to the social planning problem for which the labour allocation that maximizes the utility of the representative agent is given by the expression

$$
L_{t}=\frac{\Gamma}{2}
$$

These results demonstrate that when the bargaining weight, $\lambda$, equals one half, Classical Search Theory implements the social planning solution. ${ }^{21}$

Consider the implications of Classical Search Theory for the movement of unemployment and vacancies that one would expect to see if all output fluctuations were caused by productivity shocks. For a given value of the bargaining weight, the solution to the classical search model defines a ray through the origin in unemployment-vacancy space. If all output fluctuations were generated by shocks to productivity, those shocks would cause fluctuations

21 This result, which holds more generally in Classical Search Theory, was first proved by Arthur Hosios and is known as the Hosios condition (Hosios, 1990). 
in produced commodities and fluctuations in rental rates, land prices and the real wage. But employment, vacancies and unemployment would remain fixed.

In other words, when we use Classical Search Theory to close this model, and when we drive output fluctuations with productivity shocks, the theory implies that employment, unemployment and vacancies should be invariant over the cycle. This is not what we see in data. For search theory to fit the facts, the predominant source of fluctuations in employment must cause movements along the Beveridge curve.

\section{Model 3: Keynesian Search Theory}

To lead into a discussion of Keynesian Search Theory, it helps to understand the implications of Classical Search Theory for the relative price of land: this variable $p_{k, t} / p_{t}$ is the model analogue of the stock market and is determined in Classical Search Theory by the equation

$$
\frac{p_{k, t}}{p_{t}}=\theta\left(S_{t} \Gamma \lambda\right)^{b}
$$

where $b$ is the exponent on labour in the production function and $\theta$ is a constant that depends on the time preference rate $\beta$ and on $b$. In the Classical Search Model, asset prices fluctuate over time because labour productivity is a random variable. The Keynesian Search Model turns the relationship between the labour market and the asset market on its head.

Here is how I explained the main idea from Keynesian Search Theory in (Farmer, 2012a).

According to an often-cited passage in The General Theory, the stock market is like a beauty contest in which the judges must judge, not the beauty of the individual contestants, but how they think the other judges will rank them. One possible interpretation of that idea, in conjunction with the search model I have described, is that real labour-market outcomes are determined by self-fulfilling beliefs. To represent this idea, I propose to close the search model with the assumption

$$
\mathbb{E}_{t}\left[\frac{p_{k, t+1}}{p_{t}}\right]=x_{t}
$$

where $x_{t}$ is a process that represents how beliefs are influenced by economic events (Farmer, 2012a, p. 12).

One simple assumption about belief formation is that $x_{t}$ is constant at some value $\bar{x}_{1}$. I show in (Farmer, 2012a) that under this assumption there is a steady state equilibrium where the current value of the real price of land is also equal to $\bar{x}_{1}$, that is

$$
\frac{p_{k, t}}{p_{t}}=\mathbb{E}_{t}\left[\frac{p_{k, t+1}}{p_{t}}\right]=\bar{x}_{1}
$$

and where, for all values of $\bar{x}$ in some set $\mathcal{X} \equiv[0, \bar{X}]$, there is an equilibrium where the equilibrium value of employment $\bar{L}$, is an increasing function of $\bar{x}$.

Suppose that, at some date $T$, asset market participants are enthused with a sudden bout of optimism and $\bar{x}_{1}$ increases to some new higher value $\bar{x}_{2} \in \mathcal{X}$. Because asset traders expect that land will be more valuable in the future, they are willing to pay more for it in the current period. As they become richer, they demand more produced goods.

Firms experience an increase in the demand for their product and they shift labour into the activity of recruiting. This shift causes more competition in the labour market and 
collectively, firms find that each person allocated to the recruiting activity can successfully recruit fewer employees. Increased competition for new workers reduces the labour productivity of each firm. Since each firm was previously making zero profit, the reduction in productivity puts downward pressure on wages. The new equilibrium has a lower real wage and a higher rental rate of land with higher employment and a greater quantity of produced goods in every period.

Importantly, the new equilibrium is self-fulfilling in the sense that the higher rental rate of land generates increased income from owning land that is exactly equal to the increase required to validate the spurt of optimism that caused the increase in the price of land in the first place. In both Classical Search Theory, Model 2, and in the Keynesian Search Theory, Model 3, the price of land is equal to the discounted present value of rents. But the mechanism that links employment, rents and asset prices is different.

In Classical Search Theory, if we were to observe a stock market crash similar to the ones we observed in 1929 or in 2008 , we would be forced to conclude that rational forward-looking asset market participants correctly foresaw a big future increase in the bargaining power of workers. This event, they correctly forecast, is about to trigger an increase in the real wage, a fall in employment and a fall in the rental rate. In Keynesian Search Theory, that same confluence of events would be explained by a causal chain from a fall in optimism to a fall in wealth that triggers the increase in unemployment.

In Keynesian Search Theory, animal spirits determine the amount that people think their assets are worth. When people feel rich, they are rich.

\section{THE OBSERVATIONAL EQUIVALENCE OF THE CLASSICAL AND KEYNESIAN SEARCH MODELS}

I have explained why an economist who is wedded to Classical Search Theory would have trouble explaining why we observe a Beveridge curve in data. If productivity is the only source of shocks, the theory predicts that employment is constant. One possible modification to Classical Search Theory to explain why we observe the Beveridge curve in US and UK data is provided by theories of sticky wages and bargaining with additional sources of shocks.

One example is the paper by Galí et. al. (2012). By introducing wage-markup shocks Galí et. al. construct a version of Classical Search Theory in which the bargaining weight $\lambda$ is time varying. If one is willing to entertain this possibility, Classical Search Theory and Keynesian Theory are observationally equivalent. To see this, recall that the land price in Classical Search Theory is governed by the equation

$$
\frac{p_{k, t}}{p_{t}}=\theta\left(S_{t} \Gamma \lambda_{t}\right)^{b}
$$

where I have added a time subscript to the bargaining weight $\lambda$. Any observed time series of observations on $p_{k, t} / p_{t}$ is consistent with some sequence of time-varying bargaining weights. I do not personally find this to be a plausible way to rescue Classical Search Theory.

In a series of papers (Farmer, 2012a, p. 15), (2012b) (2015) I showed that in post WWII US data, the unemployment rate and the real value of the S\&P 500, are non-stationary and cointegrated. A persistent 30\% drop in the value of the S\&P 500 has historically been followed by a persistent increase in the unemployment rate of 13.5 percentage points (Farmer, 2015, p. 15). Why should one prefer to use Keynesian Search Theory, rather than 
Classical Search Theory with time-varying bargaining weights, to explain this fact? Here is the argument I made in (Farmer, 2012a)

... In both models, one would observe that a stock market crash is correlated with a drop in employment and a shift in the bargaining weight. But in the absence of a good theory of why the bargaining weight shifted dramatically in 1929 and again in 2008, I find it more plausible to think that the direction of causation in both cases was from self-fulfilling beliefs in the asset markets to a drop in aggregate demand. (Farmer, 2012a, p. 16)

A related approach by Gertler, Sala and Trigari (2008) and Gertler and Trigari (2009) uses overlapping contracts in a bargaining model to introduce slowly moving wages. These innovations go some way towards increasing the persistence of shocks on labour-market outcomes by introducing nominal wage rigidity implemented by long-term labour contracts. And they present a possible explanation for business cycles in normal times. But as we saw from Figure 1, downwardly rigid aggregate nominal wages do not appear to be the main culprit for the depth and persistence of output losses in the Great Depression. ${ }^{22}$

\section{KEYNESIAN SEARCH THEORY WHEN CAPITAL IS REPRODUCIBLE}

The research I summarized in sections V - VIII describes models where output is produced from land and labour. In Section IX I amend Keynesian Search Theory and I assume that output is produced from labour and reproducible capital instead of labour and land. Using this framework, I ask: If macroeconomists were to adopt Keynesian Search Theory as a microfoundation to the General Theory instead of Samuelson's neo-classical synthesis, what difference would it make?

I demonstrated in Section VII that Classical and Keynesian Search Theory remove the labour supply function, Equation (2), and I claimed that replacing that equation with the Nash bargaining equation is not a fruitful way to proceed. In the remaining sections of this paper I study two variants of Model 3, augmented by the assumption that capital is reproducible. ${ }^{23}$

I will use the symbols $Y, C, I$ and $G$ to refer to produced goods, consumption expenditure, investment expenditure and government purchases of consumption goods. That breakdown leads to the familiar accounting identity for a closed economy,

$$
Y \equiv C+I+G \text {. }
$$

In Version 1, explored in Section X, I assume that real expenditure on investment goods is driven by an exogenous process that fluctuates in a set $\mathcal{J} \equiv[0, \bar{I}]$ where $\bar{I}$ is the investment expenditure associated with full employment $L^{*}$, and where $L^{*}$ is defined as the employment level associated with maximum produced output for the function $\phi(L)$ in Figure 4. That assumption is similar to the Keynesian Cross model of textbook Keynesianism (Samuelson, 1955 ) and it is not the same assumption I made in my two Economic Journal papers (Farmer, 2012a), (Farmer, 2013).

\footnotetext{
${ }^{22}$ Supporters of the New Keynesian model argue that it was not designed to provide an explanation of the Great Depression and that, taken as a description of the operation of market economies in normal times, it has been successful. But a theory of macroeconomics should, I would argue, be capable of understanding not just "normal times' but also extreme events.

${ }^{23}$ I thank Dmitry Plotnikov for discussions about the Keynesian Search Model with capital during my supervision of his thesis (Plotnikov, 2013). The main essay from that dissertation was published in the International Journal of Economic Theory (Plotnikov, 2019).
} 
In Version 2, explored in Section XI, I define a variable $Z_{t}$ which represents the discounted present value of the return to capital, and a variable,$Z_{t}^{B}$, defined by the equation

$$
Z_{t}^{B}=\mathbb{E}_{t}\left[Z_{t+1}\right] \text {. }
$$

The variable $Z_{t}$ is the model analogue of the stock market and it corresponds to what I called $x_{t}$ in Section VI, page 17. In Section XI I assume that $Z_{t}^{B}$ fluctuates in some set $Z \equiv\left[0, \bar{Z}^{B}\right]$ where $\bar{Z}^{B}$ is the value of the stock market associated with full employment, $L^{*}$.

The models I will construct are close cousins of the RBC model which consists of the following four equations. The labour-demand equation is represented by Equation (1),

$$
(1-\alpha) S_{t}\left(\frac{K_{t-1}}{L_{t}}\right)^{\alpha}=\frac{w_{t}}{p_{t}}
$$

and the labour-supply equation, by Equation (2).

$$
\frac{\gamma C_{t}}{1-L_{t}}=\frac{w_{t}}{p_{t}}
$$

In its simplest incarnation, RBC theory combines equations (1) and (2) with an equation that explains how capital evolves through time

$$
K_{t}=K_{t-1}(1-\delta)+S_{t} K_{t-1}^{\alpha} L_{t}^{1-\alpha}-C_{t}
$$

and an equation that directs the household on the best way to allocate consumption intertemporally,

$$
\frac{1}{C_{t}}=\beta \mathbb{E}_{t}\left[\frac{1}{C_{t+1}}\left(1-\delta+\alpha K_{t}^{\alpha} L_{t+1}^{1-\alpha}\right)\right] .
$$

Equation (4), the Euler equation, is named after Leonhard Euler who was an early contributor to the mathematical theory of intertemporal optimization theory.

The parameter $\delta$ in equation (3) represents capital depreciation and the symbol $\mathbb{E}_{t}(\cdot)$ in Equation (4) is the expectations operator with respect to the known probability measure of the random variables $L_{t+1}$ and $C_{t+1}$; an interpretation that is implied by the assumption that agents have rational expectations. Equations (1) - (4) determine the evolution of consumption, capital, employment and the real wage as functions of shocks to technology, represented by the variable $S_{t}$ and the previous period's capital stock $K_{t-1}$.

A solution to the RBC model is a set of functions, $h(\cdot), g_{C}(\cdot), g_{L}(\cdot)$ and $g_{\omega}(\cdot)$, that determine the evolution of capital, consumption, employment and the real wage as functions of $S_{t}$ and $K_{t-1}$.

$$
K_{t}=h\left(K_{t-1}, S_{t}\right), \quad C_{t}=g_{C}\left(K_{t-1}, S_{t}\right), \quad L_{t}=g_{L}\left(K_{t-1}, S_{t}\right), \quad \frac{w_{t}}{p_{t}}=g_{\omega}\left(K_{t-1}, S_{t}\right) .
$$

The solution has the property that, when the variables $K_{t-1}, S_{t}, C_{t}, L_{t}$ and $w_{t} / p_{t}$ are described by these functions, equations (1) - (4) are satisfied simultaneously.

The variables $K_{t-1}$ and $S_{t}$ are called state variables and given a time series process for $S_{t}$, the evolutions of these variables are independent of the other variables of the system. The variables, $C_{t}, L_{t}$ and $w_{t} / p_{t}$ are called costate variables. Once the behaviour of capital and 
productivity are known, the costate variables are fully determined as known functions of the state variables.

According to the textbook interpretation of Keynesian economics, the Great Depression was caused by a fall in aggregate demand that was triggered by a collapse in confidence of investors. The Keynesian remedy for the fall in investment expenditure that followed was for the government to replace private investment expenditure by government purchases.

To assess the plausibility of the Keynesian explanation of the Great Depression consider the following representation of the Keynesian Search Model.

$$
\begin{gathered}
Y_{t}=C_{t}+I_{t}+G_{t}, \\
Y_{t}=S_{t} K_{t-1}^{\alpha} X_{t}^{1-\alpha}, \\
K_{t}=K_{t-1}(1-\delta)+I_{t}, \\
\frac{1}{C_{t}}=\beta \mathbb{E}_{t}\left[\frac{1}{C_{t+1}}\left\{1-\delta+\alpha \frac{Y_{t+1}}{K_{t}}\right\}\right] .
\end{gathered}
$$

Equations $(\mathrm{K} 1)-(\mathrm{K} 4)$ are four equations in five endogenous variables, $Y_{t}, I_{t}, K_{t}, C_{t}$ and $X_{t}$; the " $\mathrm{K}$ " stands for Keynesian. If this was a Classical Model, it would be closed with the assumption that labour employed to produce commodities, $X_{t}$, is equal to aggregate employment, $L_{t}$. The model would be completed first, by adding the assumption that the quantity of labour demanded is equal to the quantity of labour supplied, Equations (1) and (2),

$$
(1-\alpha) S_{t}\left(\frac{K_{t}}{L_{t}}\right)^{\alpha}=\frac{w_{t}}{p_{t}}=\frac{\gamma C_{t}}{1-L_{t}}
$$

and second, by specifying time series processes for the exogenous productivity shock $S_{t}$ and for the exogenous government expenditure variable, $G_{t}$.

My specification of Keynesian Search Theory is similar to the RBC model, but I dispense with the labour supply curve and I replace it with the assumption that aggregate demand is determined by the self-fulfilling beliefs of market participants. I will explore two ways to do that that I refer to as Version 1 and Version2.

Version 1 of Keynesian Search Theory is closed by assuming that investment is driven by an exogenous process. This assumption is modelled by Equation (K5),

$$
I_{t}=\rho_{I} I_{t-1}+\left(1-\rho_{I}\right) \bar{I}+\varepsilon_{t}^{I} .
$$

Here, $\varepsilon_{t}^{I}$ a belief shock that has zero mean and persistence $\rho_{I}$ and $\bar{I}$ is the unconditional mean of investment.

In Version 2 of Keynesian Search Theory I assume that beliefs about the stock market, I call this variable $Z_{t}^{B}$, follows the stochastic process

$$
Z_{t}^{B}=\rho_{B} Z_{t-1}^{B}+\left(1-\rho_{B}\right) \bar{Z}^{B}+\varepsilon_{t}^{B} .
$$


The variable $\varepsilon_{t}^{B}$ in Equation (K6) is a belief shock that has zero mean, $\rho_{B}$ is the persistence of $Z_{t}^{B}$ and $\bar{Z}^{B}$ is its unconditional mean.

The 'stock market' is defined to be the discounted present value of future returns to capital,

$$
Z_{t}=\mathbb{E}_{t}\left[\frac{1}{R_{t}}\left(\alpha Y_{t+1}+Z_{t+1}\right)\right]
$$

where, $R_{t}=1-\delta+Y_{t+1} / K_{t+1}$ is the real interest rate between dates $t$ and $t+1$. Beliefs about the future value of the stock market are connected to realizations of the stock market by the rational expectations assumption,

$$
Z_{t}^{B}=\mathbb{E}_{t}\left[Z_{t+1}\right]
$$

Notice that expectations are exogenous and driven by the backward-looking equation (K6). But they are also rational in the sense that beliefs are self-fulfilling. This apparent contradiction arises from the fact that the underlying model of the labour market is closed by Keynesian Search Theory in which firms and households are assumed to be price takers. I showed in Section VI that when market participants are price takers, even in the steady state there are not enough equations to pin down a point on the Beveridge curve. As a consequence, the Keynesian Search Model displays steady-state indeterminacy. This is very different from first-generation models of dynamic indeterminacy of the kind described in the survey article by Benhabib and Farmer (Benhabib \& Farmer, 1999).

\section{FOUR EXPERIMENTS IN THE KEYNESIAN SEARCH MODEL (VERSION 1).}

In this section, I present the results of four experiments in which I study the impact of temporary and permanent shocks to investment and government purchases. In these experiments, I use Version 1 of the Keynesian Search Model as a computational laboratory. The experiments are designed to illustrate the strengths of the model as an explanation of the Great Depression and of the recovery from the Depression that occurred when the US engaged in a massive fiscal expansion at the onset of WWII.

Figure 5 contains two panels. The upper panel reports the impulse response functions for a temporary shock to investment of $10 \%$. The lower panel reports the impulse response functions for a temporary shock to government purchases of the same magnitude. In both panels, I show how GDP, consumption, investment, government purchases, the capital stock, the stock market, the expected stock market and the real return to capital respond to these two different impulses. All responses, with the exception of the interest rate, are in units of percentage deviations from the steady state. The interest rate response is in units of level deviations from the steady state. Thus 0.5 is a move of 50 basis points above the steady state interest rate.

\section{Experiment 1: A temporary shock to investment}

In Experiment 1, I assume that the world begins in a stationary perfect-foresight nonstochastic steady-state equilibrium. At some date $T$, (this is date 2 on the figures) an individual, or a group of investors is enthused with a bout of optimism. These are the people who run the firms. Investors at date $T$ believe there to be a profit-making opportunity by building new factories. Note that, at this date, and only at this date, the perfect foresight assumption is violated. 


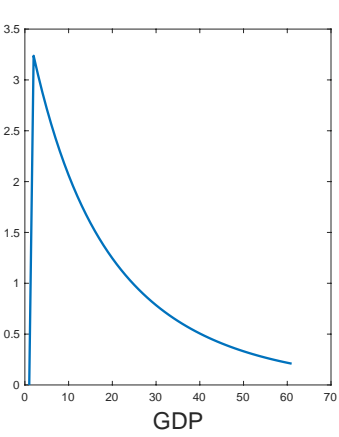

A Temporary Shock to Investment
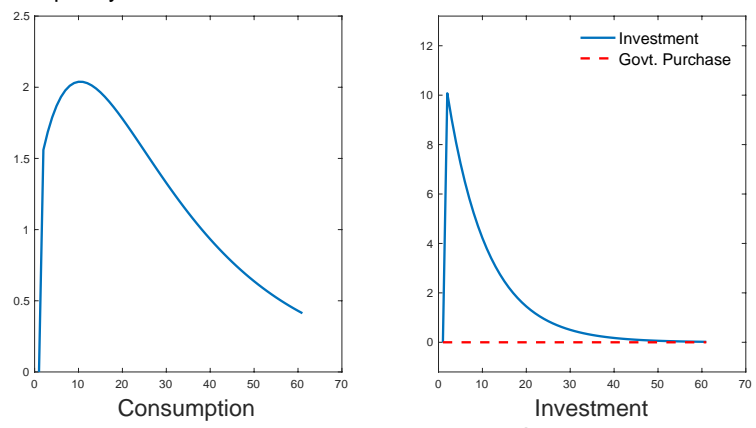

\& Govt. Purchases
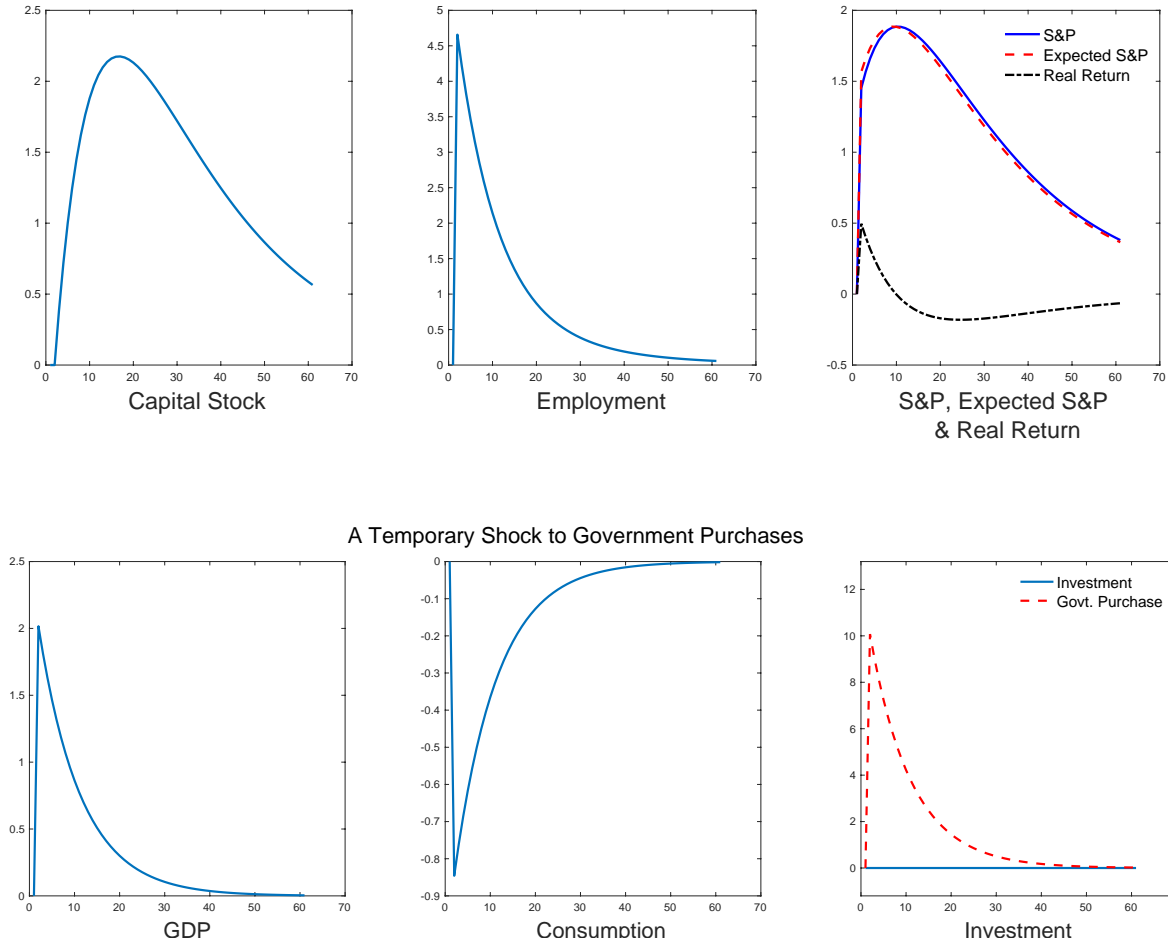

A Temporary Shock to Government Purchases
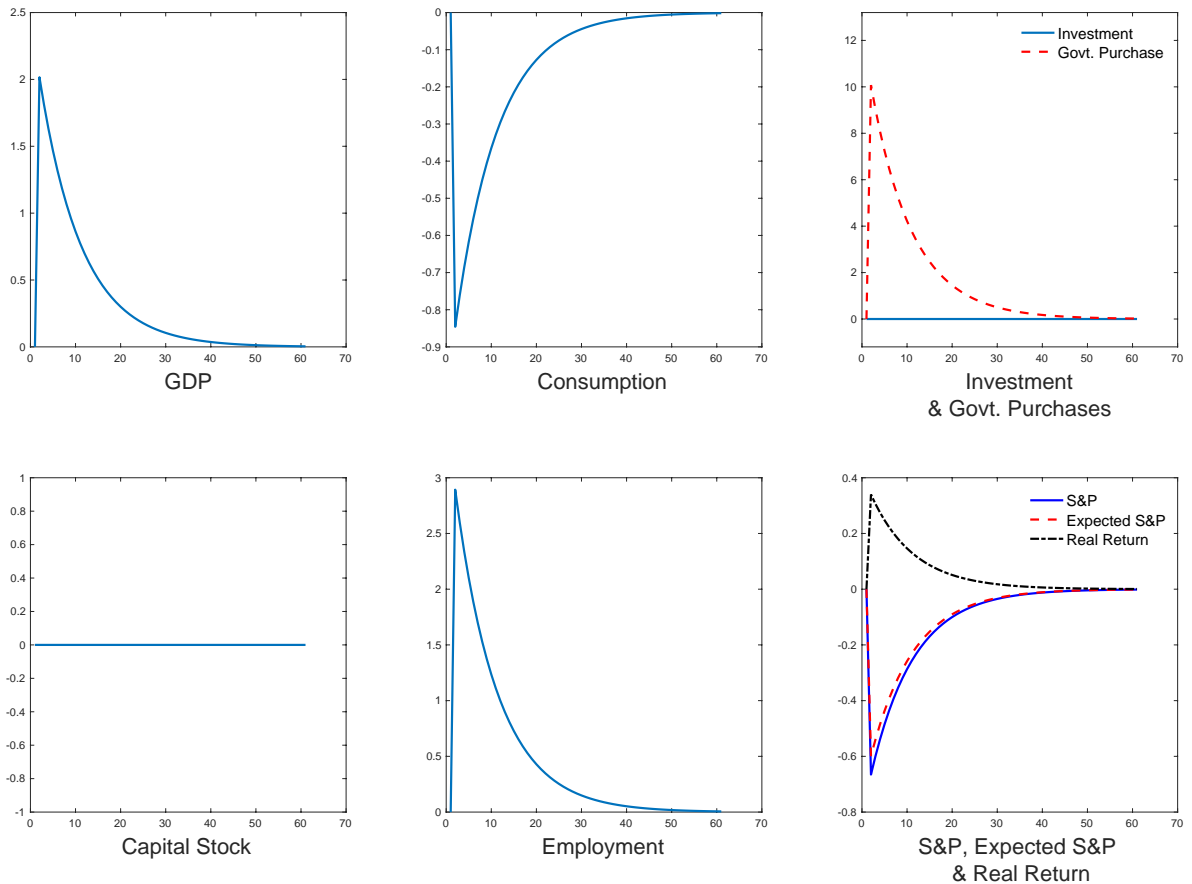

Figure 5: Temporary Shocks to Investment and Government Purchases ${ }^{24}$

${ }^{24}$ The panel reports the returns of GDP, consumption, investment, government purchases, the capital stock and employment in productive activity for sixty quarter after the shock. The parameters were calibrated to $\beta=$ 0.992, $\delta=0.04$ and $\alpha=0.3$. 
Households at date $T-1$ had the opportunity to purchase a real pure discount bond for price

$$
Q_{T-1}=\frac{1}{1+r_{T-1}}
$$

or to hold shares in firms that $\operatorname{cost} Z_{T-1}$ units of consumption goods and that paid a gross exdividend return of ${ }^{25}$

$$
R_{T-1}=\frac{\alpha Y_{T}+Z_{T}}{Z_{T-1}}=1+r_{T-1}
$$

These two rates of return are equal for all dates $t<T$. They are also equal at all dates $t>T$, as households and firms have perfect foresight of all future prices and quantities. But at date $T$, the equivalence is broken as the event that triggers a burst of spontaneous optimism is assumed to be unanticipated.

The optimism of investors increases the equity value of firms. The managers of the firms use the increased equity to purchase additional capital and the additional investment causes the corporate sector as a whole to expand by employing additional workers. The increased competition for workers reduces labour productivity temporarily as firms assign a larger proportion of their workers to recruiting. Competition drives down real wages, but the wage bill as measured by $(1-\alpha) Y_{T}$ goes up as additional workers are recruited to meet the increased demand for investment goods.

At date $T$, households are wealthier for two reasons. First, the equity value of their asset holdings has increased and second, they correctly anticipate that they will have additional labour income in the future. The present value of their additional wealth depends on the rate at which the bout of optimism declines and accounts for the difference between Figure 5, which assumes that the shock to investment is temporary and declines by $10 \%$ every quarter, and Figure 6, which assumes that it is permanent.

The interest rate between dates $T$ and $T+1$ is the first rate to change. It increases at date $T$ by 50 basis points as market participants correctly anticipate that the ratio of GDP to capital will begin to decline at date $T+1$ and that consumption will increase initially and then decline. These interest rate movements are consistent with both the Euler equation and with the marginal productivity of capital schedule after accounting for the employment movements that occur in equilibrium.

When $\rho_{I}=0.9$, the half-life of a shock to investment is ten quarters. The top panel of Figure 5 shows that consumption, employment and GDP all increase as a consequence of a burst in spontaneous optimism. ${ }^{26}$ Consumption and capital display a hump-shaped pattern which is characteristic of impulse response functions estimated in U.S. data (Sims, 1989). Government consumption does not move because it is determined by Equation (K9) and I have assumed that there is no feedback from the economy to government consumption.

\footnotetext{
${ }^{25}$ An ex-dividend share costs $Z_{T-1}$ at date $T-1$. The purchaser receives the dividend payment $\alpha Y_{T}$ and can resell the share for $Z_{T}$ at date $T$.

${ }^{26}$ I have been somewhat cursory in my description of the labour market and in the figures presented in Sections $\mathrm{X}$ and XI. I have treated employment used in production interchangeably with aggregate employment. In Keynesian Search Theory (Farmer, 2012a) (2013) these variables are distinct. For calibrations in which labour turnover is high, as it is in US data, the approximation $L_{t}=X_{t}$ is not a bad one as I showed in Figure 4. Approximately $12 \%$ of US workers change jobs every quarter (Bureau of Labor Statistics , 2019).
} 
For the calibration I picked in Figure 5, a 10\% increase in investment causes a $3.25 \%$ increase in GDP, a $2 \%$ increase in consumption and a $4.5 \%$ increase in employment. The value of equity increases by $2 \%$ and remains elevated 60 quarters later. The real interest rate increases by about 10 basis points and declines relatively rapidly to its steady state which, for this model, is equal to the time preference rate of the representative family.

\section{Experiment 2: A temporary shock to government consumption}

In experiment 2 , the event that occurs at date $T$ is an unanticipated increase in government purchases of $10 \%$ that declines at $10 \%$ per quarter thereafter. The impulse responses for this experiment are depicted in the lower panel of Figure 5.

The immediate response of the corporate sector is similar to the response to an investment shock. Firms experience an increase in demand, they shift the proportion of workers from production to recruitment and total employment increases by about $3 \%$. The response of consumption and investment is, however, quite different from the case of an investment shock. Investment is governed by Equation (K5) and this is unaffected by the boost in government consumption purchases. And because investment is unchanged, the capital stock also remains unaffected by a boost in government expenditure.

The effect of an unanticipated increase in government consumption on GDP is roughly twothirds of that of an unanticipated increase in investment. Unlike the investment effect, consumption falls, rather than rises, in response to a government consumption shock. Consumers spend less because their wealth falls. This drop in wealth is reflected in the stock market, which falls by a little more than half percentage point. It is also reflected in a fall in after tax labour income which drops independently of whether the increase in government purchases is financed by debt or taxes.

Because this model is Ricardian in the sense of Barro (Barro R. J., 1974), household wealth is the same whether the increase in government purchases is financed from debt or taxes. ${ }^{27}$ If government finances its increased expenditure by borrowing, households choose to hold all of the increased debt and their consumption falls to reflect this decision. If government purchases are financed by lump-sum taxes, the after-tax value of household income falls by the same amount.

The responses to a temporary government purchase shock is consistent with the evidence from WWII where consumption fell even as employment and GDP increased. ${ }^{28}$ It is perhaps unsurprising that a temporary increase in government consumption expenditure does not mimic the effects of a temporary increase in private investment expenditure. An investment shock adds to productive capital. A government consumption shock does not.

\section{A discussion of experiments 1 and 2}

In experiment 1 I showed that, in response to a temporary shock to investment, consumption investment and employment all move in the same direction. These co-movements are consistent with the data from the Great Depression, some of which I presented in Figure 2. In experiment 2, I showed that in response to a temporary shock to government purchases, employment and GDP increase but consumption falls. These co-movements are consistent with the data from WWII in which employment, investment and GDP all increased, but

\footnotetext{
${ }^{27}$ For an example of a model with Keynesian Search Theory and non-Ricardian consumers see (Farmer \& Plotnikov, 2012).

${ }^{28}$ (Farmer, 2012b, p. 705).
} 
consumption fell, a point that I discussed in Chapter 10 of my 2016 book Prosperity for All (Farmer, 2016, pp. 155-181).

Experiments 1 and 2 highlight an important difference of Keynesian Search Theory from more traditional interpretations of Keynesian economics in which consumption is a function of income. Keynes famously claimed that digging holes and filling them in would be capable of restoring full employment. ${ }^{29}$ In the model that he set out in The General Theory, the associated stimulus from government consumption was predicted to lead not only to an increase in employment and GDP, but also to an increase in consumption. Because the Keynesian Search Model is closed with a theory in which consumption is a function of wealth rather than income, the prediction that consumption will increase in response to an increase in government purchases fails to hold.

How do these predictions change when the shocks generating investment and government purchases are permanent? To answer that question, Figure 6 contains two panels that plot the impulse response functions of GDP, consumption, investment, government consumption, employment, the stock market and the interest rate for the cases when $\rho_{I}$ and $\rho_{G}$ are equal to 1. For these parameter values, shocks to investment and shocks to government consumption are permanent.

\section{Experiment 3: A permanent shock to investment}

Consider the impact of a permanent shock to investment of $10 \%$. The impulse responses for this shock are plotted on the upper panel of Figure 6 . This panel shows that a permanent $10 \%$ increase in investment expenditure leads to a $10 \%$ permanent increase in GDP, capital and employment that builds up slowly and still has not achieved its full effect after 80 quarters. Employment quickly achieves a new equilibrium, 10\% higher than its initial level.

Consumption and capital increase more gradually, eventually attaining new steady states where each of them also increase by $10 \%$.

These impulse responses are very different from those that occur in the New Keynesian model and they reflect the fact that Keynesian Search Theory contains a continuum of steady state equilibria. As long as the economy is operating below full employment, a permanent change in investment will induce a permanent increase in economic activity. If investment is non-stationary, this behaviour will be reflected in the other variables in the model.

\section{Experiment 4: A permanent shock to government consumption}

On the lower panel of Figure 6 I have depicted the impulse response functions for GDP, consumption, investment, capital and employment following a permanent $10 \%$ increase in government purchases of consumption goods. This panel shows that this shock leads to a permanent reduction in consumption of $10 \%$ and no change in investment, capital, employment or GDP.

The result that government purchases crowd out consumption may seem counter-intuitive in a Keynesian model. We have come to expect that there is a substantial government expenditure multiplier when the economy is operating at less than full employment. The crowding out result follows from two assumptions. First, in Version 1 of the Keynesian model, investment is exogenous. Second, the assumption of a representative agent implies that the household and the government budget constraints are two sides of the same coin. A permanent increase in government consumption imposes an implicit tax liability on

\footnotetext{
${ }^{29}$ Keynes (1936, p. 129).
} 

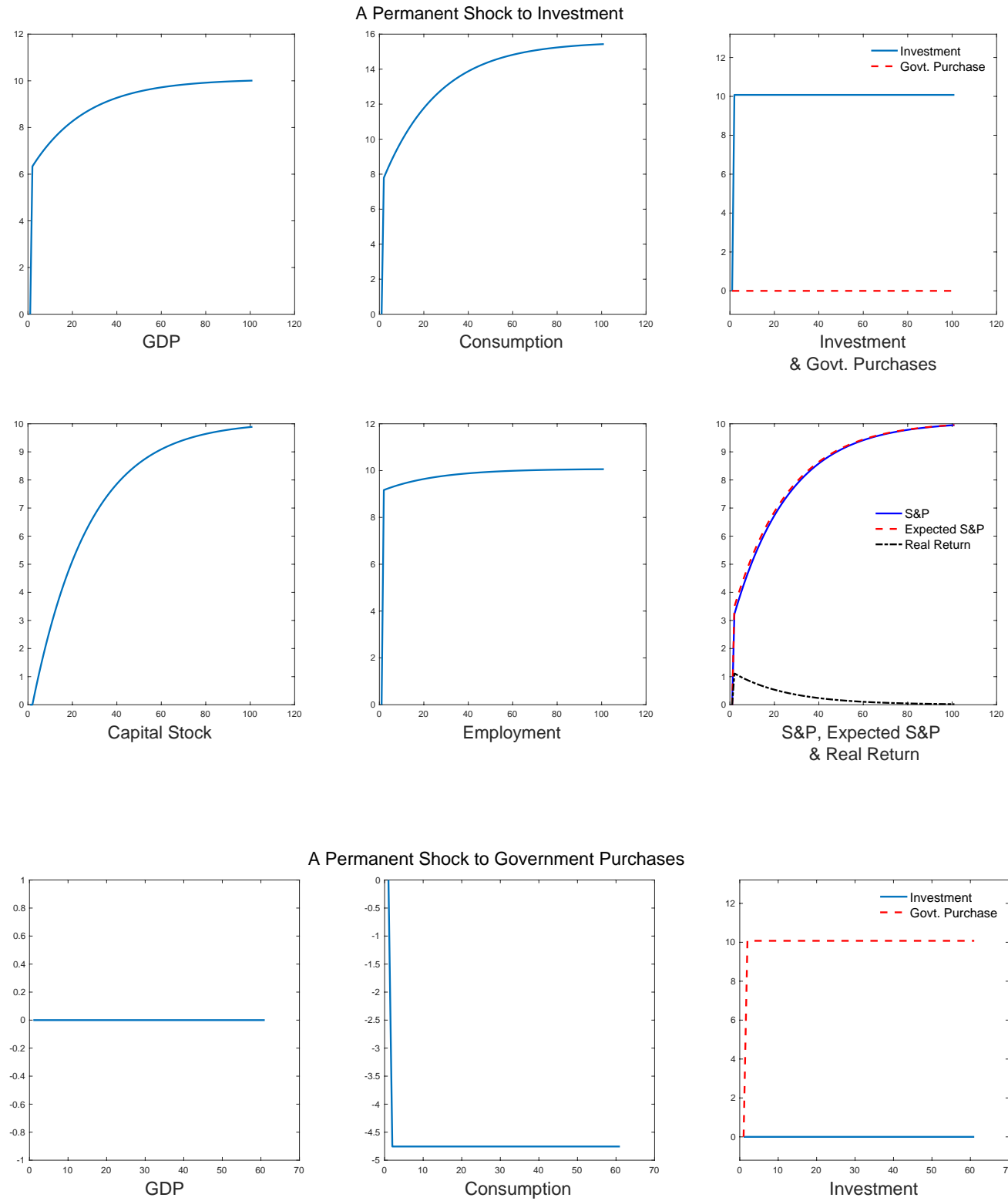

A Permanent Shock to Government Purchases
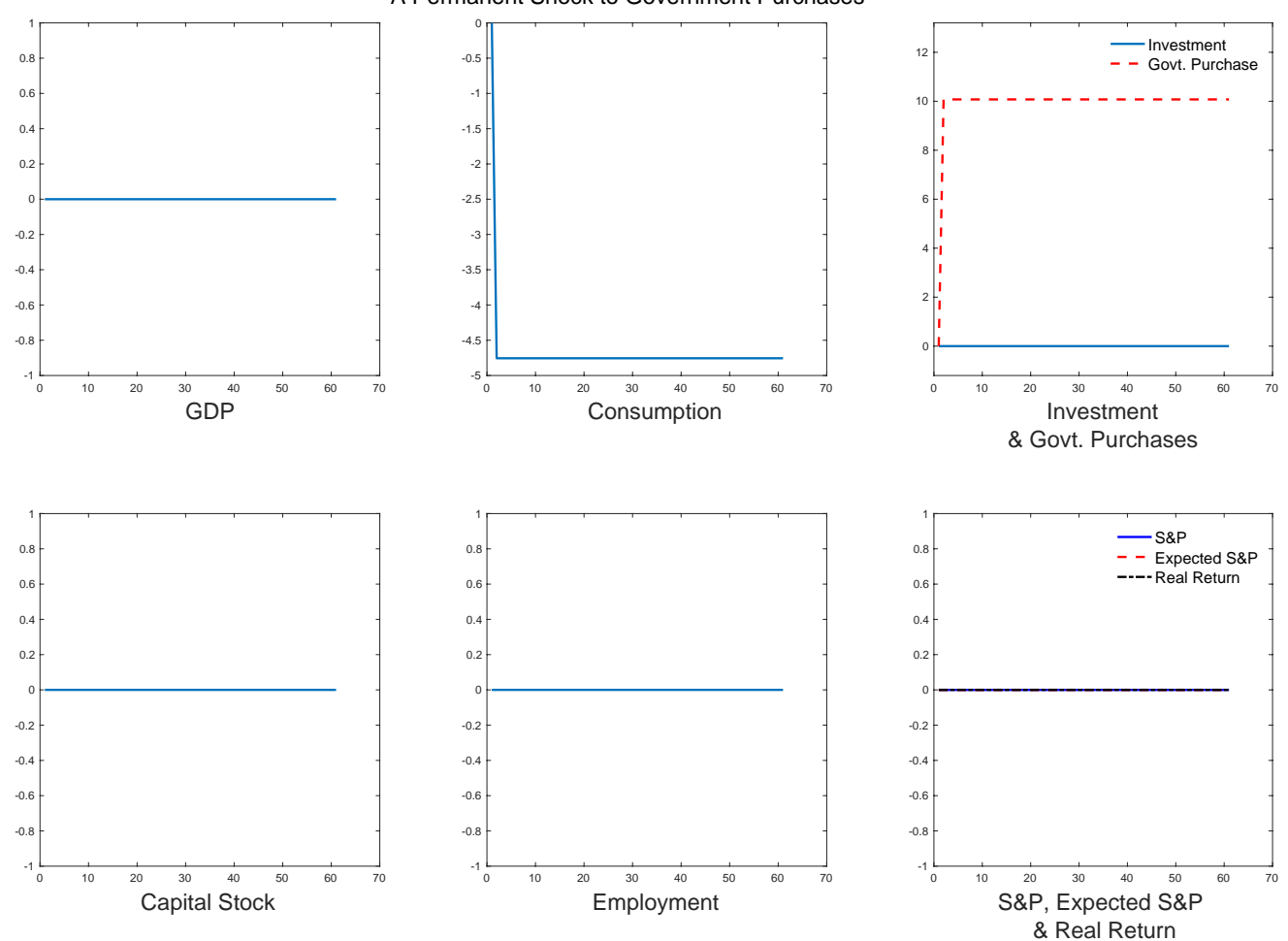

Figure 6: Permanent Shocks to Investment and Government Purchases 
households and, recognizing this liability, households reduce consumption permanently and immediately in the face of a government consumption increase in order to maintain solvency.

It is important to stress that, in the Keynesian Search Model, belief shocks have permanent effects. This feature is very different from the New-Keynesian model in which the economy is characterized by small fluctuations around a social planning optimum. In the Keynesian Search Model, permanent deviations from the optimal unemployment rate can cause large permanent losses to GDP.

\section{TWO EXPERIMENTS IN THE KEYNESIAN SEARCH MODEL (VERSION 2).}

In this section I explore Version 2 of the Keynesian Search Model which I close by assuming that beliefs about the future value of the stock market are fundamental. I capture that assumption with equations (K6), (K7) and (K8), reproduced below,

$$
\begin{gathered}
Z_{t}^{B}=\rho_{B} Z_{t-1}^{B}+\left(1-\rho_{B}\right) \bar{Z}+\varepsilon_{t}^{B}, \\
Z_{t}=\mathbb{E}_{t}\left[\frac{1}{R_{t}}\left(\alpha Y_{t+1}+Z_{t+1}\right)\right], \\
Z_{t}^{B}=\mathbb{E}_{t}\left[Z_{t+1}\right] .
\end{gathered}
$$

Equation (K6) describes the evolution of the belief shock. Equation (K7) defines $Z_{t}$ to be the expected discounted present value of a claim to future capital income and Equation (K8) imposes the assumption that expectations are rational. I refer to $Z_{t}$ interchangeably as the stock market or as the $S \& P$ and I refer to $Z^{B}$ as the stock-market belief or the Expected $S \& P$.

\section{Experiment 5: A temporary shock to consumer confidence}

In experiment 5 I study the impact on the endogenous variables of a shock to beliefs. I model this shock as an increase in beliefs about the present value of future capital income; this is the variable $Z_{t}^{B}$ in equation (K6). Because the initial effect of this shock is on consumer spending, I will refer to it in this discussion as a shock to consumer confidence.

The upper panel of Figure 7 plot the impulse responses of the variables of the model to a shock to $Z_{t}^{B}$ of 10 basis points. The narrative associated with this version of Keynesian Search Theory is quite different from that of Version 1 and it has different implications for the co-movements of the endogenous variables.

At date $T$, (this occurs at date 2 on Figure 7), households become spontaneously more optimistic about the future value of their assets and this increase causes them to demand additional consumption goods. The upper panel of Figure 7 depicts the effect of this spontaneous bout of consumer optimism when the optimistic belief decays at a rate of $10 \%$ per quarter.

To meet the increased demand for consumption goods, firms switch workers into the recruiting activity and at the same time, they hire more workers and purchase additional capital goods to meet an anticipated future increase in demand. For the calibration I used to draw this figure, GDP increases in period $T$ by $1.5 \%$, investment increases by $6 \%$ and employment goes up by $2 \%$. 

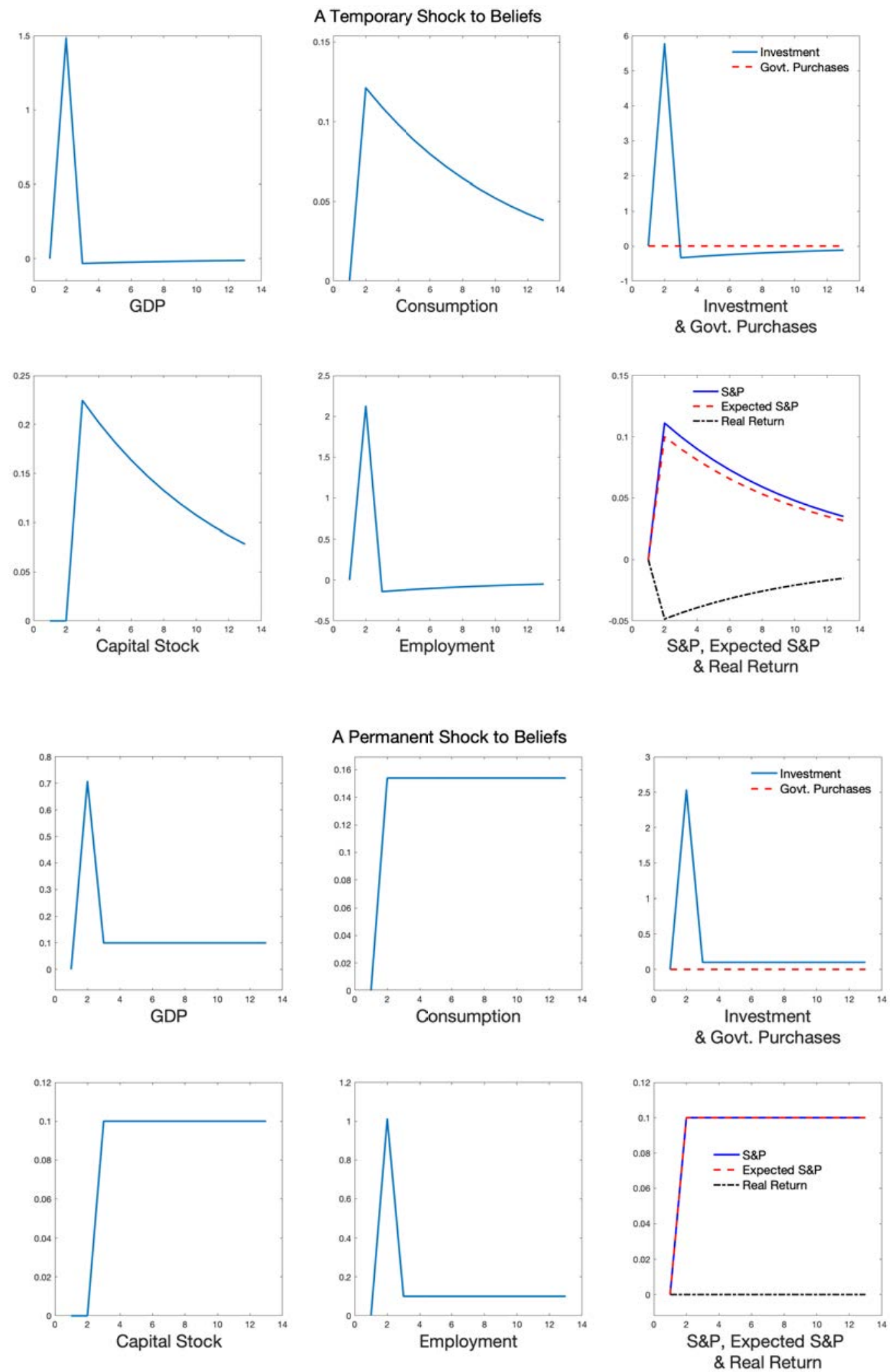

Figure 7: Temporary and Permanent Shocks to Beliefs 
The real interest rate between dates $T$ (the date of the shock) and $T+1$ falls because market participants correctly forecast that the GDP increase was temporary and at $T+1$ GDP will drop back but the economy will have substantially more capital. The additional capital is used to produce additional consumption goods for the foreseeable future at the expense of reduced investment.

\section{Experiment 6: A permanent shock to beliefs about the stock market}

Consider next, the impact of a permanent shock to consumer confidence. The lower-panel of Figure 7 shows that a shock of this kind increases investment expenditure at date $T$ by roughly one third of the magnitude of a temporary shock and is followed by a reduction to a new permanently higher level of investment expenditure. The impact effects of a permanent belief shock on GDP and employment are also more muted than the impact effect of a temporary shock. Importantly a permanent shock to consumer confidence has a permanent effect on GDP, employment, investment and the capital stock.

\section{Why it matters if we use Keynesian Search Theory to understand the macroeconomy}

In Section IX, I posed the question: If macroeconomists were to adopt the Keynesian Search Model as an alternative micro-foundation to The General Theory instead of Samuelson's neoclassical synthesis, what difference would it make?

The first big difference is in the way that econometricians should analyse time-series data. The New-Keynesian model is well described by a stationary vector autoregression in which economic shocks disturb a self-correcting system that returns quickly to a steady state. The Keynesian Search Model is instead described by a Vector Error Correction Model in which permanent shocks to beliefs cause permanent shocks to the unemployment rate.

The prediction that asset prices and the unemployment rate are non-stationary but cointegrated was studied by Beyer and Farmer (Beyer \& Farmer, 2007), Farmer (Farmer, 2012b) (Farmer, 2015), Arabaci, (Arabaci, 2017) and Pan (Pan, 2020) for US data, Fritsche and Pierdzioch (Fritsche \& Pierdzioch, 2016) for Germany and Pan (Pan, 2018) for a sample of international economies. Farmer and Nicolò (Farmer \& Nicolò, 2018) showed that a monetary version of Keynesian Search Theory provides a better fit to US inflation dynamics than the NK Phillips curve, a finding that is confirmed in Canadian and UK data (Farmer \& Nicolò, 2019). These papers are all consistent with a model in which non-stationary beliefs drive real economic activity and they are difficult to reconcile with the NK model of a selfcorrecting economic system.

The second big difference is in the welfare costs of bad economic policy. The steady state of the New Keynesian model is at or close to a social planning optimum and although the equilibrium may temporarily differ from the planning optimum, the welfare costs of business cycles in many versions of the New Keynesian model are small (Galí, Gertler, \& LópezSalido, 2007). In contrast, Keynesian Search Theory predicts that the economy may remain a long way from the social planning optimum for considerable periods of time.

Finally, I have drawn attention to the difference between recessions driven by investor confidence and recessions driven by animal spirits in the asset markets. The fact that these two driving impulses have quite different implications for the magnitude and duration of comovements suggests that they may be distinguished empirically. If beliefs about asset values are the driving force behind major recessions, the right way to deal with future financial crises, as I argued in Prosperity for All (Farmer, 2016), is through coordinated central bank and treasury support of the asset markets. 
If Keynesian Search Theory is a better description of the economy we inhabit, and I believe it is, active stabilization policies by central banks and national treasuries have an important role to play. That role is not simply to stabilize temporary shocks; it is to ensure that market economies attain maximum sustainable employment in the long-run.

\section{CONCLUSION}

What should the reader take away from the analysis in this paper? Keynesian Search Theory represents an alternative paradigm that has very different policy implications than those implied by New Keynesian economics. These alternative implications stem from two sources.

First, a market economy, if left to itself, does not display a self-stabilizing mechanism to restore full employment. This is in contrast to the New-Keynesian economics in which active policy may perhaps speed up the return to full employment, but where business cycles are minor wrinkles around a social planning optimum.

Second, Keynesian Search Theory explains how beliefs may become self-fulfilling prophecies. This paper has explored two mechanisms by which beliefs may operate. It is an important question, as to which of these mechanisms is a more accurate description of the real world.

If investment is exogenous, the only way to restore the optimal capital stock is through public investment. If stock-market beliefs are exogenous, treasury or central bank intervention in the asset markets, is a more effective means of restoring full employment than fiscal policy. In either scenario, fiscal intervention through increased government consumption will not be effective at maintaining full employment in the face of permanently depressed beliefs about the value of private assets.

Over the past forty years, New Keynesian macroeconomists have formalized the elegant verbal theory of business cycles described by (Pigou, 1923). While this is a considerable intellectual achievement, it does not bear much relationship to Keynesian economics. The Indeterminacy School has a history that stretches back for more than thirty years. It is my hope that macroeconomists will continue to build upon the ideas developed in this school by recognizing that indeterminacy is not a problem to be sidestepped, but an inherent property of general equilibrium models. Models with indeterminacy provide an elegant and consistent way of providing a foundation to the central ideas of Keynes' General Theory.

\section{REFERENCES}

Andolfatto, D. (1996). Business Cycles and Labor-Market Search. American Economic Review, 86(1), 112-132.

Arabaci, O. (2017). Testing for cointegration with threshold effect between unemployment and stock prices. Applied Economics Letters, 25(9), 643-647.

Barro, R. J. (1974). Are Government Bonds Net Wealth? Journal of Political Economy, 82(6), 1095-1117.

Barro, R. J., \& King, R. G. (1984). Time-Separable Preferences and IntertemporalSubstitution Models of Business Cycles. Quarterly Journal of Economics, 99(4), 817-839 .

Benhabib, J., \& Farmer, R. E. (1999). Indeterminacy and sunspots in macroeconomics. In J. Taylor, \& M. Woodford, The Handbook of Macroeconomics (pp. 387--448). New York: North Holland. 
Beningno, G., \& Fornaro, L. (2018). Stagnation Traps. The Review of Economic Dynamics, $85(3), 1427-1470$.

Beyer, A., \& Farmer, R. E. (2007). Natural Rate Doubts. Journal of Economic Dynamics and Control, 31(121), 797-825.

Bureau of Labor Statistics . (2019, October 9th). News Release. Retrieved from BLS: https://www.bls.gov/news.release/pdf/jolts.pdf

Cherrier, B., \& Saïdi, A. (2018). The Indeterminate Fate of Sunspots in Economics. History of Political Economy, 50(3), 425--481.

De Vroey, M. (2016). A History of Macroeconomics. Cambridge: Cambridge University Press.

Eggertsson, G., Mehrotra, N., \& Robbins, J. A. (2019). A Model of Secular Stagnation: Theory and Quantitative Evaluation. American Economic Journal: Macroeconomics, $11(1), 1--48$.

Farmer, R. E. (1993). The Macroeconomics of Self-Fulfilling Prophecies. Cambridge, MA: MIT Press.

Farmer, R. E. (2008a). Old Keynesian Economics. In R. E. Farmer (Ed.), Macroeconomics in the Small and the Large (pp. 23-43). Cheltenham, UK: Edward Elgar.

Farmer, R. E. (2008b, March). Aggregate Demand and Supply. International Journal of Economic Theory, 4(1), 77-94.

Farmer, R. E. (2010). Expectations, Employment and Prices. New York: Oxford University Press.

Farmer, R. E. (2010a, April). How the Economy Works: Confidence, Crashes and Selffulfilling Prophecies. New York: Oxford University Press.

Farmer, R. E. (2010b). How to reduce unemployment: A new policy proposal. Journal of Monetary Economics, 57, 557-572.

Farmer, R. E. (2012a). Confidence Crashes and Animal Spirits. Economic Journal, 122, 155-172 .

Farmer, R. E. (2012b). The Stock Market Crash of 2008 Caused the Great Recession: Theory and Evidence. Journal of Economic Dynamics and Control, 36, 696--707.

Farmer, R. E. (2013). Animal Spirits, Financial Crises and Persistent Unemployment. Economic Journal, 123(568), 317--340.

Farmer, R. E. (2014). The Evolution of Endogenous Business Cycles. Macroeconomic Dynamics.

Farmer, R. E. (2015). The Stock Market Crash Really Did Cause the Great Recession. Oxford Bulletin of Economics and Statistics, 77(5), 617-633.

Farmer, R. E. (2016). Prosperity for All: How to Prevent Financial Crises. New York: Oxford Univesity Press.

Farmer, R. E. (2020, April). The Indeterminacy School in Macroeconomics. (K. Kuttner, Ed.) Retrieved May 2020, from Oxford Research Encyclopedia of Economics and Finance: https://oxfordre.com/economics/view/10.1093/acrefore/9780190625979.001.0001/acr efore-9780190625979-e-511 
Farmer, R. E., \& Nicolò, G. (2018). Keynesian Economics without the Phillips Curve. Journal of Economic Dynamics and Control, 89, 137--150.

Farmer, R. E., \& Nicolò, G. (2019). Some International Evidence for Keyesian Economics without the Philips Curve. Journal of Economic Dynamics and Control, In Press.

Farmer, R. E., \& Platonov, K. (2019). Animal Spirits in a Monetary Economy. European Economic Review, 115, 60--77.

Farmer, R. E., \& Plotnikov, D. (2012, April). Does Fiscal Policy Matter? Blinder and Solow Revisited. Macroeconomic Dynamics, 16(Supplement 1), 149-166.

Fritsche, U., \& Pierdzioch, C. (2016). Animal spirits, the stock market, and the unemployment rate: Some evidence from German data. Economics Bulletin, 37(1), 205--213.

Galí, J., Gertler, M., \& López-Salido, J. D. (2007). Markups, gaps and the welfare costs of business fluctuations. Review of Economics and Statistics, 89(1), 44-59.

Galí, J., Smets, F., \& Wouters, R. (2012, January). Unemployment in an Estimated New Keynesian Model. NBER Macroeconomics Annual, 26(1), 329-360.

Gelain, P., \& Guerrazzi, M. (2010). A DSGE Model from the Old Keynesian Economics: An Empirical Investigation. Centre for Dynamic Macroeconomic Analysis: WP Series.

Gertler, M., \& Trigari, A. (2009). Unemployment Fluctuations with Staggered Nash Wage Bargaining. Journal of Political Economy, 117(1), 38-86.

Gertler, M., Sala, L., \& Trigari, A. (2008). An Estimated DSGE Model with Unemployment and Staggered Wage Bargaining. Journal of Money Credit and Banking, 40(8), 17131764.

Guerrazzi, M. (2011). Search and stochastic dynamics in the old keynesian economics: A rationale for the Shimer puzzle. Metroeconomica, 62(4), 561-586.

Guerrazzi, M. (2012). The "Farmerian" approach to ending finance-induced recession: Notes on stability and dynamics. Economic Notes, 41, 81-89.

Hansen, A. (1936). Mr. Keynes on Underemployment Equilibrium. Journal of Political Economy, 44(5), 667-686.

Heathcote, J., \& Perri, F. (2018). Wealth and Volatility. The Review of Economic Studies, $85(4), 2173-2213$.

Hicks, J. R. (1937, April). Mr. Keynes and the Classics: A Suggested Interpretation. Econometrica, 5(2), 147-159.

Hicks, J. R. (1939). Value and Capital (2nd Edition, 1946 ed.). Oxford: The Clarendon Press.

Hosios, A. (1990). On the efficiency of matching and related models of search and unemployment. Review of Economic Studies, 57, 279-298.

Keynes, J. M. (1936). The General Theory of Employment, Interest and Money. Edinburgh: MacMillan and Co.

Kocherlakota, N. (2011). Bubbles and Unemployment. Mimeo: Federal Reserve Bank of Minneapolis.

Kocherlakota, N. (2012). Incomplete Labor Markets. Federal Reserve Bank of Minneapolis, mimeo. 
Kydland, F. E., \& Prescott, E. C. (1982). Time to Build and Aggregate Fluctuations. Econometrica, 50, 1345-1370.

Long, J. B., \& Plosser, C. I. (1983). Real Business Cycles. Journal of Political Economy, 91(1), 39-69.

Lucas Jr., R. E. (1972). Expectations and the Neutrality of Money. Journal of Economic Theory, 4, 103-124.

Merz, M. (1995). Search in the Labor Market and the Real Business Cycle. Journal of Monetary Economics, 36, 269-300.

Miao, J., Wang, P., \& Xu, L. (2015). Stock market bubbles and unemployment. Economic Theory, 61(2), 273-307.

Michaillet, P., \& Saez, E. (2015). Aggregate Demand, Idle Time, and Unemployment. Quarterly Journal of Economics, 130(2), 507--569.

Pan, W.-F. (2018). Does the stock market really cause unemployment? A cross-country analysis. The North American Journal of Economics and Finance, 44, 34-43.

Pan, W.-F. (2020). How does the macroeconomy respond to stock market fluctuations? The role of sentiment. Macroeconomic Dynamics, 24(2), 421-446.

Patinkin, D. (1956). Money, Interest and Prices: An Integration of Monetary and Value Theory. Evanston Ill.: Row, Peterson and Co.

Pearce, K. A., \& Hoover, K. D. (1995). After the Revolution: Paul Samuelson and the Textbook Keynesian Model. History of Political Economy, 27(5), 183-216.

Phelps, E. S. (1970). Microeconomic Foundations of Employment and Inflation Theory. (E. S. Phelps, Ed.) New York: Norton.

Pigou, A. C. (1923). Industrial Fluctuations. London: McMillan.

Pissarides, C. (1990). Equilibrium Unemployment Theory. Oxford: Basil Blackwell.

Plotnikov, D. (2013). Three Essays on Macroeonomics with Incomplete Factor Markets. Ph.D. dissertation, UCLA.

Plotnikov, D. (2019). Hysteresis in Unemployment: A Confidence Channel. International Journal of Economic Theory, 15(1), 109--127.

Robinson, J. (1978). Contributions to Modern Economics. Oxford: Academic Press.

Samuelson, P. A. (1955). Economics: An Introductory Analysis (3rd Ed.). McGraw Hill.

Shea, P. (2013). Learning by Doing, Short-sightedness and Indeterminacy. Economic Journal, 569(1), 738-763.

Sims, C. A. (1989, May). Models and Their Uses. American Journal of Agricultural Economics, 71, 489-494. 